\title{
SPRÁVA O ARCHEOLOGICKOM VÝSKUME KOSTOLA SV. MIKULÁŠA V KOVARCIACH (OKRES TOPOLČANY) V ROKOCH 2016-2019
}

\author{
MÁRIO BIELICH
}

Abstrakt: Príspevok prináša prvé informácie o archeologickom výskume barokového Kostola sv. Mikuláša v Kovarciach, okr. Topol’̌any. Výskum sa uskutočnil v rokoch 2016-2019 a bol vyvolaný stavebnými aktivitami v blizkosti kostola. Počas archeologického výskumu bolo odkrytých a zdokumentovaných niekol'ko nových stavebných objektov: menšia miestnost'v severozápadnom rohu kostola, krypta pod severnou sakristiou, východná čast' zaniknutého polygonálneho presbytéria staršieho gotického kostola a ohradový múr kostolného cintorína. Podarilo sa zdokumentovat' aj tri stredoveké hroby. Južne od kostola sme preskúmali aj niekol'ko sidliskových objektov z neskorého stredoveku a novoveku. V krypte pod sakristiou sme zdokumentovali pozostatky A. Welsa z konca 19. storočia (pradedo britskej herečky A. Hepburn). Materiálna kultúra získaná počas výskumu dokumentuje život vobci v 13.-20. storoči a hrobovú výbavu druhej polovice 19. storočia.

Klúčové slová: Slovensko - Kovarce - sakrálna architektúra - kostolný cintorín - materiálna kultúra neskorého stredoveku a novoveku - krypta A. Welsa (pradedo Audrey Hepburn).

A report on the archaeological research into the Church of St. Nicholas in Kovarce, Topol'čany district, in 2016-2019

Abstract: This contribution brings the first information about the archaeological research into the baroque Church of St. Nicholas in Kovarce, Topolčany district. The research took place in the years 2016-2019 and was triggered by construction activities in close proximity of the church. The archaeological research uncovered and documented several new features: a small room in the north-west corner of the church, a crypt underneath the north sacristy, the east section of a former polygonal presbytery of an older, Gothic church and a wall encircling the churchyard. The research also involved three medieval graves. South of the church several settlement features from the late Middle Ages and the modern age were investigated. In the crypt under the sacristy the archaeologists identified the remains of A. Wels (great-grandfather of the British actress A. Hepburn) from the late 19th century. Material culture acquired in the course of the research documents life in the town in the 13th-20th centuries, as well as grave goods from the second half of the 19th century.

Key words: Slovakia - Kovarce - sacral architecture-churchyard-material culture from late medieval to post medieval period - crypt of A. Wels (great-grandfather of Audrey Hepburn).

\section{Úvod}

Príspevok prináša prvé informácie o menšom záchrannom archeologickom výskume barokového Kostola sv. Mikuláša v Kovarciach v rokoch 2016-2019. Výskum bol vyvolaný stavebnými aktivitami pri rekonštrukcii kostola a priniesol mnoho nových poznatkov o vývoji kostola a jeho okolia od stredoveku až po 20. storočie. V predmetnom texte sú obsiahnuté aj prvé analýzy nálezov, ktoré boli počas výskumu objavené.

\section{Lokalizácia}

Obec Kovarce leží na nive rieky Nitry a pozdíž náplavových kužel’ov jej l’avostranných prítokov. Skúmaná poloha sa nachádza na rovine v blízkosti cesty spájajúcej Kovarce s Ludanicami. Kostol je situovaný v bezprostrednej blízkosti kaštiel'a a v centre súčasnej dediny. V minulosti sa v okolí kostola nachádzala vol'ná plocha ohraničená ohradou kostola. Z pedologického hladiska je terén v okolí kostola tvorený hnedozemou, ktorá sa do okolia barokového kostola dostala v polovici 18. storočia počas terénnych vyrovnávacích úprav po ukončení výstavby. Pod hnedozemou sa nachádza žlté sprašové podložie (Mazúr-Lukniš 1986, 165). 


\section{Prehl’ad doterajšieho bádania}

Najstaršie praveké osídlenie obce pochádza z polohy Hôrky v okolí Kaplnky sv. Anny. Na tejto polohe sa našlo niekol'ko úštepov z radiolaritu čokoládovej farby, ktoré sa nepodarilo bližšie datovat'. Je možné, že tieto nálezy korešpondujú s najmladšou fázou paleolitických kultúr (gravettien) zachytených na strednom Ponitrí. Obdobie neolitu je v obci Kovarce spojené s polohou Dielce, kde bolo zachytené sídlisko kultúry s lineárnou keramikou (Klčo-Illášová 1993, 11). Sídlisko lengyelskej kultúry bolo zistené v blízkosti mlyna Alberta Zicha (tamže, 11). Z danej polohy je doložené aj sídlisko z eneolitu, staršej a mladšej doby bronzovej (Mitáš-Žáčik 2011, 195). V katastri obce sa nachádza aj hradisko lužickej kultúry z neskorej doby bronzovej až z doby halštatskej na vrchu Vel'ký Tríbeč (Wiedermann 1985, 28; Veliačik-Romsauer 1994, 87; Katkinová-Katkin 2002, 83; Mitáš-Žáčik 2011, 195). Stredoveké osídlenie je doložené pri mlyne Alberta Zicha, kde A. Ruttkay identifikoval sídlisko z 9. storočia (Ruttkay 1973). Intenzita osídlenia katastra obce narastá $\mathrm{v}$ priebehu 12.-13. storočia. V katastri obce evidujeme štyri polohy s nálezmi keramiky z tohto obdobia: Vinohrad (Wiedermann 1987); Humnište (Rod 1954); Dielec (Rod 1954a) a mlyn a okolie (Ruttkay 1973). Vrcholnostredoveké nálezy boli zistené aj pri kopaní základov pivnice vedl’a rímskokatolíckej fary (Mitáš-Žáčik 2011, 195). Kovarce sa prvýkrát v písomných prameňoch spomínajú pod názvom Koarch. Od roku 1280 až do začiatku 14. storočia bola obec majetkom rodiny Ludanickovcov. Následne sa stala majetkom král'a. Neskôr vlastníctvo obce prešlo rukami viacerých majitel'ov, až sa nakoniec stala súčast'ou panstva Aponiovcov. Obec dostala právo slobodného trhu v 14. storočí a svojím vývojom prerástla do funkcie mesta. V 15. storočí sa tu rozvinuli remeslá ako čižmárstvo a hrnčiarstvo. Po výprave bega Mehmeda na Slovensko v roku 1530 bolo vyrabované a vypálené celé Ponitrie vrátane Kovariec (http://www.obeckovarce. sk/historia-obce.html). Osídlenie obce v tomto období naznačujú nálezy neskorostredovekej keramiky, ktoré v záhrade domu pána Pecháča v roku 1979 zozbierala G. Březinová (1979). Po vytlačení osmanských vojsk z krajiny v roku 1687 sa postupne začal oživovat’ hospodársky život. V rokoch 1755-1756 bol postavený nový barokový Kostol sv. Mikuláša na mieste pôvodného gotického kostola (obr. 1). Donátorkami výstavby kostola boli tri vdovy: Judita Berenyi, vdova po Ondrejovi Zayovi, Juliana Otlik, vdova po Ladislavovi Korlátkoy a Terézia Korlátkoy, vdova po Jozefovi Aponyi. V roku 1864 postavila firma Wels a Wehle v obci cukrovar (Vlastivedný slovník obcí 1977, 83, heslo Kovarce).

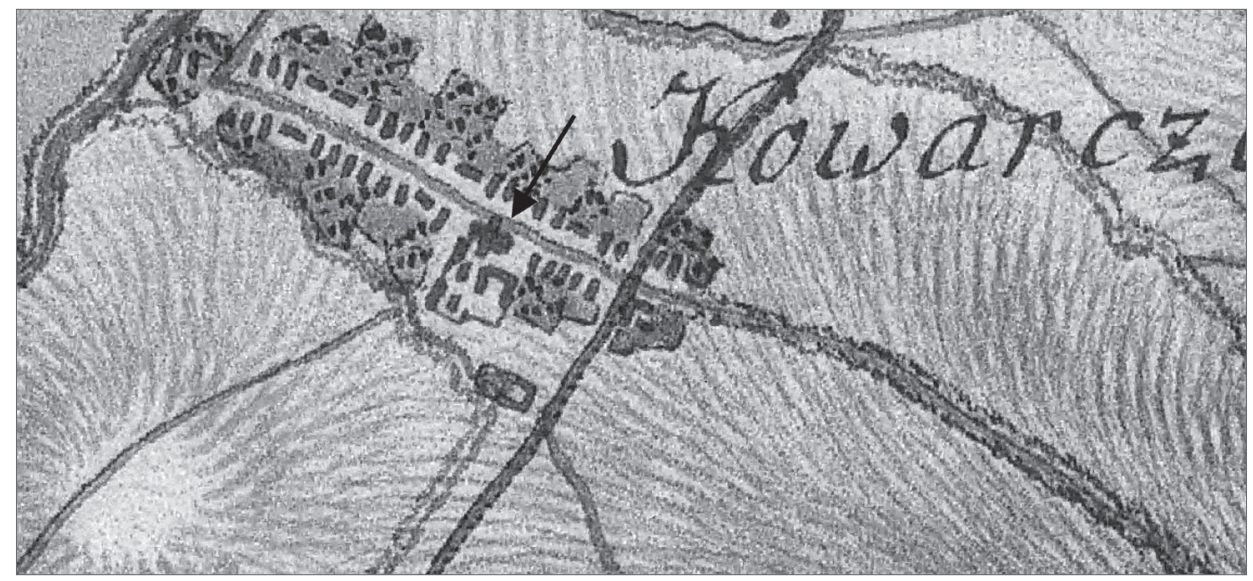

Obr. 1. Kovarce zobrazené na prvom vojenskom mapovaní. Zdroj https://mapire.eu/en/.

Abb. 1. Kovarce auf der ersten militärischen Kartierung. Quelle https://mapire.eu/en/. 


\section{Vyhodnotenie výsledkov archeologického výskumu}

Záchranný archeologický výskum kostola trval štyri roky. V roku 2016 sme skúmali teplovodnú prípojku ku kostolu a ryhy bleskozvodu (sondy 1-5). V roku 2017 sme sledovali výkopy odvlhčovacej ryhy v interiéri kostola (sondy 6 a 7). V roku 2018 sme v rámci prípravy revitalizácie okolia Kostola sv. Mikuláša vykopali východne a západne od kostola zist’ovacie sondy, ktorých cielom bolo identifikovat' priebeh ohradového múru cintorína (sondy 8-10A-10D). V roku 2019 sme pokračovali výskumom južne od kostola. Zachytili sme zvyšky novovekého sídliska s nálezmi z vrcholného stredoveku a novoveku (sondy 10E-10K). Postupne sme identifikovali niekol'ko nových stavebných objektov Kostola sv. Mikuláša a čast’ neskorostredovekej a novovekej dediny (obr. 2).

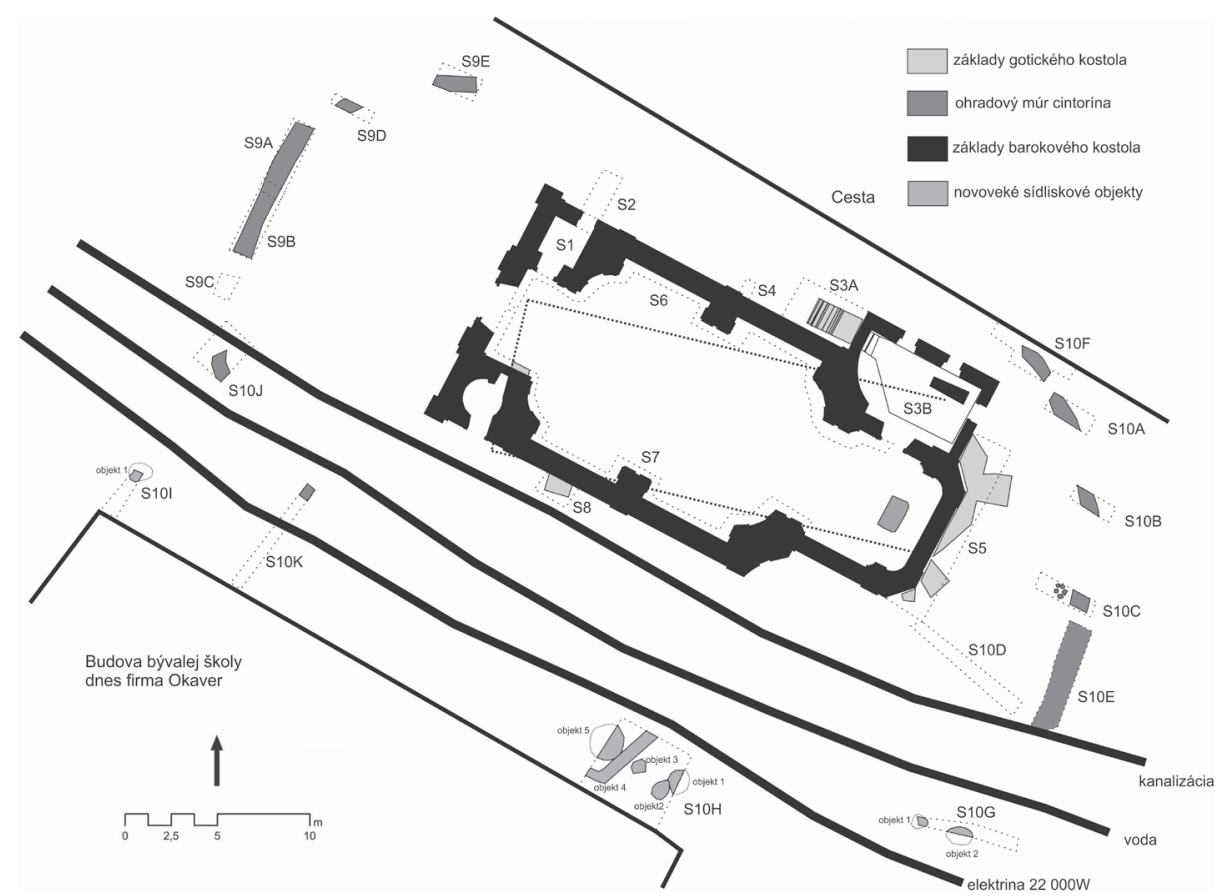

Obr. 2. Kovarce, Kostol sv. Mikuláša s jednotlivými sondami archeologického výskumu z rokov 2016-2019. Spracovali M. Bielich, M. Bartík, A. Nemergut.

Abb. 2. Kovarce, St. Nikolauskirche mit den einzelnen Sondierschnitten der archäologischen Grabung von 2016-2019. Bearbeitet von M. Bielich, M. Bartík, A. Nemergut.

\section{Sonda 1/2016}

Sonda 1 sa nachádzala v severozápadnom rohu barokového kostola. Ide o menšiu miestnost’, ktorá slúžila na uskladňovanie pomôcok na údržbu kostola. V rovnakej časti, ale v juhozápadnom rohu, sa nachádza schodisko na chór. Rozmery miestnosti sú $200 \times 200 \mathrm{~cm}$. Podlahu v mieste sondy tvorila mramorová biela dlažba (rozmery $30 \times 50 \mathrm{~cm}$ ) vybudovaná v 50 . rokoch 20 . storočia. Po odstránení mramorovej podlahy sme pod jemným maltovým lôžkom objavili pôvodnú barokovú tehlovú podlahu, ktorá bola tvorená z tehiel s odtlačkami písmen C I B. Ide o donátorku kostola 
Comes Judith Beréni, manželku Ondreja Zaia. Táto podlaha sa nachádzala na $10 \mathrm{~cm}$ hrubom zhutnenom sutinovom zásype priamo nad klenbou dutého priestoru narušeného výskumnými prácami v západnej časti miestnosti. V strede miestnosti sme identifikovali tehlový štvorec s pôdorysom $100 \times 100 \mathrm{~cm}$. Pri rozoberaní štvorca sa nám podarilo pod jednou z tehiel objavit' dva dvadsat'halierniky z rokov 1921 a 1924 (určil J. Hunka). Počas stavebných úprav v 20. rokoch 20. storočia bola tehlová podlaha rozobraná $\mathrm{v}$ priestore štvorca $\mathrm{v}$ strede miestnosti. Pod ňou sa nachádza kruhový otvor s priemerom $50 \mathrm{~cm}$, ktorý bol otvorený a znovu zamurovaný. Ten sme následne otvorili a dostali sme sa do dutého priestoru zaklenutého valenou klenbou, ktorý mal vnútorné rozmery $140 \times 140 \mathrm{~cm}$ a bol celý zasypaný stavebnou sutinou. Tá sa dovnútra dostala cez tento kruhový otvor. Na dne priestoru, v híbke $161,73 \mathrm{~m} \mathrm{n}$. m., bola zachytená tehlová dlažba. V strede podlahy sa nachádzal rovnako ako na vrchu štvorec s pôdorysom $100 \times 100 \mathrm{~cm}$. Najmladší zásah v tomto priestore nastal v 70. rokoch 20. storočia, ked' boli v juhovýchodnom rohu miestnosti uložené elektrické siete, pričom bola zničená baroková tehlová podlaha. Siet' bola uložená do plastovej rúry a zaliata betónom, pri rozbíjaní betónu bol objavený plechový vrchnáčik z piva Zlatý bažant, ktorý bol používaný v 70. rokoch 20. storočia. Funkcia dutého zaklenutého priestoru je diskutabilná, mohlo íst' o priestor detskej hrobky, alebo osária, alebo o miestnost' na ukladanie vzácnych predmetov z kostola. Žial', obsah priestoru bol v 20. rokoch 20. storočia znehodnotený, a teda ostáva neznámy.

\section{Sonda 2/2016}

Sonda 2 s rozmermi $200 \times 100 \times 250 \mathrm{~cm}$ sa nachádzala pri severnej stene kostola oproti sonde 1 , ktorá bola v interiéri. Terén v mieste sondy tvorila plocha s povrchom z udupanej hliny. Pod hlinou sa nachádza kultúrna vrstva, ktorá vznikla pri úpravách terénu po výstavbe kostola v druhej polovici 18. storočia. V celej ploche i híbke obdížnikovej sondy boli zistené tri zásypové vrstvy. Najvrchnejšia vrstva vznikla pri posledných terénnych úpravách v druhej polovici 20. storočia. Súvisí s budovaním betónovej obruby okolo základov kostola, ktoré boli obnažené na kameň. Druhá, žltá zásypová vrstva súvisí priamo s výstavbou kostola v druhej polovici 18. storočia. Pod touto vrstvou sa nachádza ílovité žlté podložie, ktorého mocnost' je podla geológov minimálne 5 metrov. V híbke 162,95 m n. m. sme v ílovitom podloží zdokumentovali kostrový hrob (hrob 1). Tento hrob pochádza z kostolného cintorína gotického kostola, ktorý bol prestavaný v baroku.

\section{Opis hrobu}

Hrob 1, orientácia JZ-SV, zachytená hlava a horné končatiny; hrob neobsahoval žiadne prídavné predmety; datovanie: neskorý stredovek až novovek.

\section{Sonda $3 A / 2016$ a $3 B / 2016$}

Sonda 3A s rozmermi $200 \times 400 \times 160 \mathrm{~cm}$ sa nachádzala v exteriéri sakrálnej stavby, pri západnej stene severnej sakristie (obr. 3). V celej ploche i hĺbke obdížnikovej sondy bola zistená jedna zásypová vrstva tvorená stavebnou sutinou. Táto vrstva vznikla po sanácii vstupu do krypty, ktorá sa nachádzala pod severnou sakristiou. K tejto stavebnej úprave došlo na konci 30. rokov 20. storočia, alebo v prvých rokoch druhej svetovej vojny. Sonda 3A odkryla západný vstup do krypty pod severnou sakristiou. Do sakristie sa vstupovalo po ôsmich schodoch, ktoré boli vykopané do barokového zásypu a podsypané žltým pieskom. Schody boli tvorené tehlami, ktoré mali jeden roh zaoblený. Tehly boli kladené zvisle na kant. Pred vstupom do krypty sa nachádzalo menšie tehlové plató, ktorého rozmery boli $120 \times 120 \mathrm{~cm}$. Počas druhej svetovej vojny schody rozobrali a následne nimi uzavreli vstup do krypty, potom asanovali celú budovu vstupu a zasypali ňou vchod. Interiér krypty sme označili ako sondu 3B. V krypte je uložená bronzová rakva A. Welsa. Vnútorné rozmery krypty sú $400 \times 360 \mathrm{~cm}$. Krypta je prekrytá valenou tehlovou 


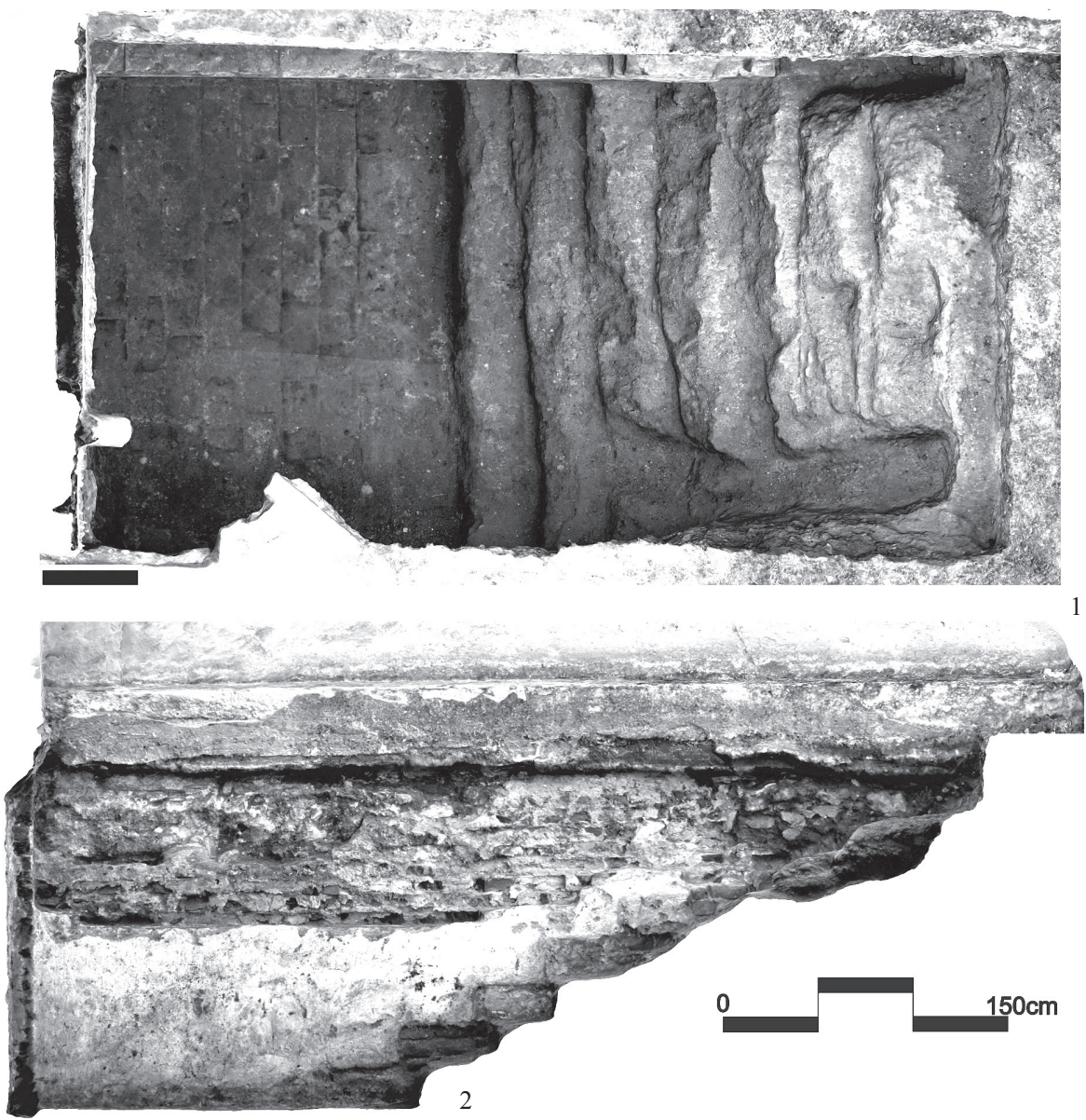

Obr. 3. Kovarce, Kostol sv. Mikuláša, sonda 3A. Vstupné schodisko do krypty pod severnou sakristiou. Vyhotovili M. Bielich, B. Balžán.

Abb. 3. Kovarce, St. Nikolauskirche, Sondierschnitt 3A. Eingangstreppe zur Krypta unter der Nordsakristei. Erstellt von M. Bielich, B. Balžán.

klenbou. Vnútorný priestor je omietnutý bielou omietkou. Podlaha je tehlová. Rakva sa nachádza v severnej časti krypty (obr. 4).

Opis rakvy

Železná rakva sa skladala z dvoch častí. Vrchná čast’ rakvy bola vplyvom klimatických podmienok pokrytá cínovou koróziou a lokálne aj železnými nátekmi zo stropu hrobky, ktorý bol spevnený železnou výstužou. Na povrchu sa z väčšej časti vytvoril tzv. cínový mor, ktorý miestami prenikol až do híbky a spôsobil tak perforáciu povrchu. Na všetkých štyroch rohoch je odlievané olovené zdobenie s rastlinným motívom a stredná čast' bočných strán je zdobená olovenými anjelmi v tvare hlavy s krídlami, prichytenými nitmi a drôtom z farebného kovu (med'). Z vnútornej časti veka je viditel'né bodové spájanie jednotlivých častí olovenou spájkou. Niektoré 


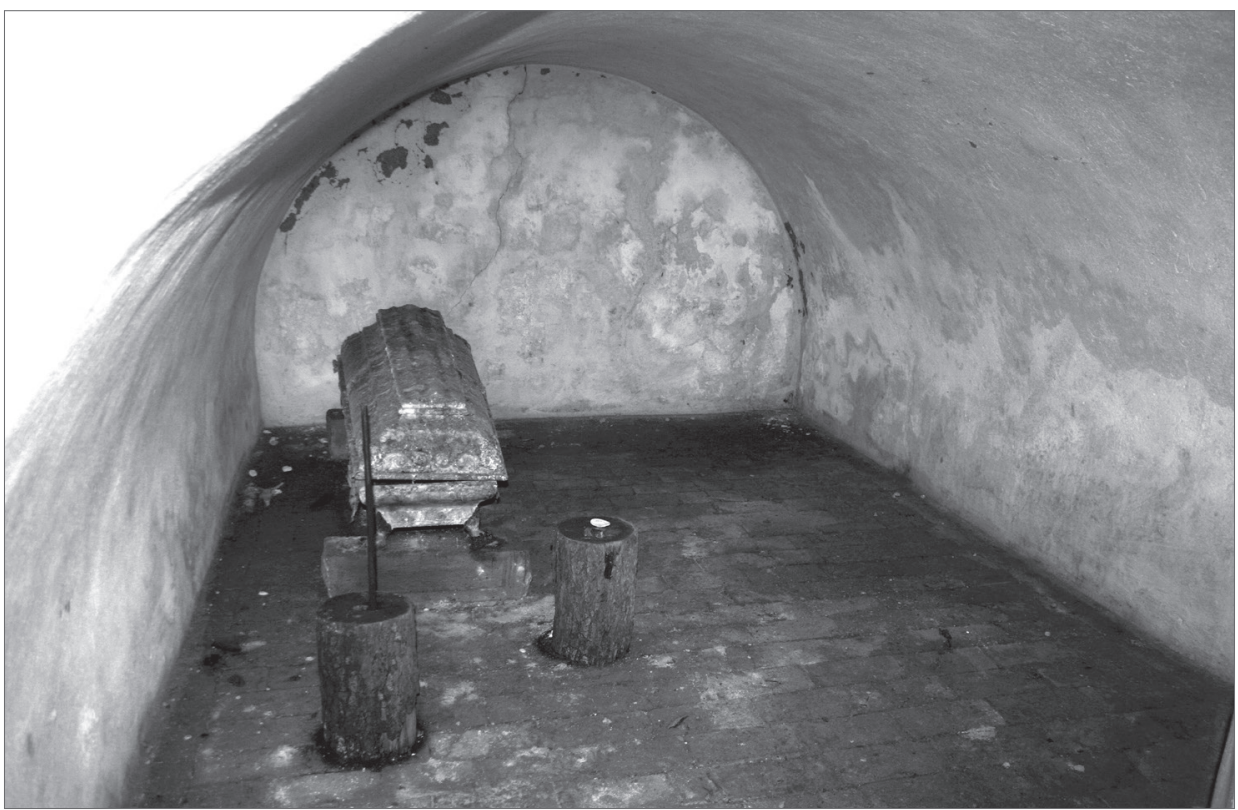

Obr. 4. Kovarce, Kostol sv. Mikuláša, sonda 3B. Interiér krypty s kovovou rakvou. Foto M. Bielich.

Abb. 4. Kovarce, St. Nikolauskirche, Sondierschnitt 3B. Innenraum der Krypta mit Metallsarg. Foto M. Bielich.

spoje boli prasknuté. Dlhšiu čast’ obruby po oboch stranách lemujú po tri ozdobné kovania so skrutkami v podobe hlavy anjela, ktoré slúžili na prichytenie veka k spodnej časti rakvy. Skrutky sú zdobené olovenou hlavičkou v tvare štylizovaného kvetu. Tri skrutky chýbali. Spodná čast' rakvy bola poškodená radikálne. Najviac na dne a spodnej časti bočných strán vplyvom kyselín vytvorených pri rozklade tela. Dve tretiny dna boli silne prekorodované a rozpadnuté. Dolná čast' bočných strán bola prekorodovaná a rozpadnutá. Železná pásovina, ktorá spevňovala spodnú čast' rakvy utrpela na dne najviac a úplne chýbala. Na vonkajšej strane v spodnej časti je bordúra $\mathrm{s}$ rastlinným motívom z farebného kovu poškodená koróziou a v strednej časti úplne chýbala. Na malej časti zostali zvyšky pôvodného zdobenia farbou so zlatým leskom, na ktorom vidiet' aj t’ahy štetcom. Celá rakva stojí na štyroch nohách v tvare levích láb zo zliatiny železa, ktoré boli pokryté koróziou. Na prednom čele spodnej časti rakvy bol štítok výrobcu: ERQ RAUNER M:KOPORSÓK GYÁRA ARADON a číslo 5698/17. Vedl'a rakvy bol spadnutý železný kríž, ktorý bol pôvodne pripevnený na vrchnej časti rakvy.

\section{Sonda 4/2016}

Sonda 4 s rozmermi $60 \times 60 \times 60 \mathrm{~cm}$ sa nachádzala $\mathrm{v}$ exteriéri, v strede severnej steny lode Kostola sv. Mikuláša. Išlo o menšiu zistovaciu sondu, ktorá reagovala na potrebu odstránenia vrstvy betónu zo základov barokového kostola. Vo výkope sondy 4 bola zachytená iba jedna vrstva, ktorá vznikla pravdepodobne pri výstavbe kostola v druhej polovici 18. storočia.

\section{Sonda 5/2016}

Sonda 5 s rozmermi $200 \times 800 \times 80 \mathrm{~cm}$ sa nachádzala východne od presbytéria a sakristie Kostola sv. Mikuláša. Pod udupanou hlinou sa nachádza kultúrna vrstva, ktorá vznikla pri úpravách terénu 
po výstavbe kostola v druhej polovici 18. storočia. V sonde 5 sa podarilo zachytit' východnú čast' presbytéria staršieho gotického Kostola sv. Mikuláša (obr. 5). Pracovne môžeme predpokladat', že šírka presbytéria bola $800 \mathrm{~cm}$. Identifikovali sme dva zo štyroch rohov z polygónu presbytéria. Š́rka základov sa nedala spresnit', pretože základy gotického kostola sú spojené so základmi barokového kostola. Absolútna híbka základov je $162,71 \mathrm{~m} \mathrm{n}$. $\mathrm{m}$. V sonde 5 sme na styku východného múru presbytéria a oporného piliera 1 urobili rez po základovú škáru. V zist’ovacom reze sme zachytili dva hroby vo vel'mi fragmentárnom stave. Hroby rešpektovali staršiu stavbu, neboli narušené základmi gotického kostola a zdá sa, že prislúchajú najskôr k neskorostredovekému kostolnému cintorínu. Zistili sme, že základy presbytéria boli v prvom metri budované ako poloblúk a následne sa prešlo na polygonálne presbytérium. Porovnanie vzoriek malty uskutočnil T. Haviar, ktorý zistil zhodu pri maltách. ${ }^{1}$ Ide teda o jednu stavebnú fázu. Kostol sv. Mikuláša vznikol v období gotiky (13.-14. storočie) a svojmu účelu slúžil až do prvej polovice 18. storočia, kedy bol rozobratý a na jeho mieste vznikla nová sakrálna stavba, pričom patrocínium sv. Mikuláša zostalo zachované. Už u gotického kostola sa prejavili statické problémy, ktoré sa riešili vybudovaním oporných pilierov. Jeden sa nachádzal pri východnom múre a druhý pri juhovýchodnom rohu presbytéria.

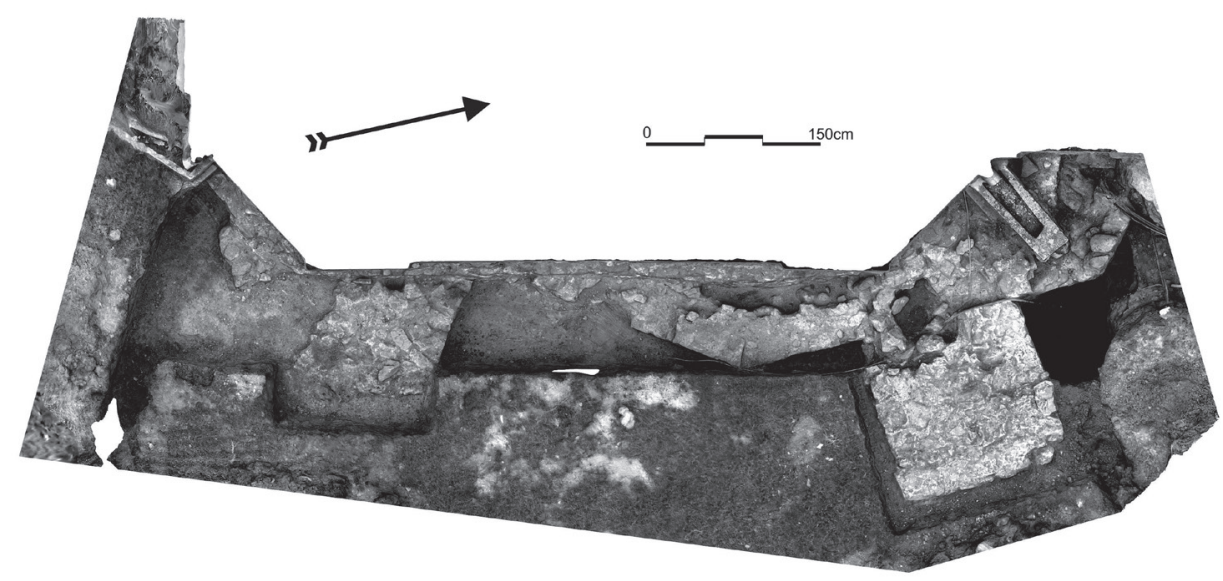

Obr. 5. Kovarce, Kostol sv. Mikuláša, sonda 5. Zachytené východné murivo presbytéria gotického kostola. Vyhotovili M. Bielich, B. Balžán.

Abb. 5. Kovarce, St. Nikolauskirche, Sondierschnitt 5. Erfasstes östliches Mauerwerk des Chorraums der gotischen Kirche. Erstellt von M. Bielich, B. Balžán.

\section{Opis hrobov}

Hrob 2, orientácia SZ-JV, zachytená hlava a fragmenty končatín; hrob neobsahoval žiadne prídavné predmety; datovanie: neskorý stredovek až novovek.

Hrob 3, orientácia SZ-JV, zachytené len horné končatiny; hrob neobsahoval žiadne prídavné predmety; datovanie: neskorý stredovek až novovek.

1 Za informáciu d’akujem Mgr. art. T. Haviarovi. 


\section{Sonda $6 / 2017$}

Sonda 6 s rozmermi $40 \times 2300 \times 40 \mathrm{~cm}$ sa nachádzala v interiéri pri severnej stene Kostola sv. Mikuláša. Realizovala sa počas odvlhčovania (drenáže) obvodových stien kostola a siahala od severozápadného rohu pri vstupe do kostola až po vstup do severnej sakristie. Plochu v mieste sondy 6 tvorila mramorová dlažba vybudovaná v 50. rokoch 20. storočia. Mramorová dlažba bielej farby mala rozmery $30 \times 50 \mathrm{~cm}$, hrúbka bola $4 \mathrm{~cm}$. Pod mramorom sa nachádzalo až $10 \mathrm{~cm}$ vyrovnávacieho betónu. Pod vrstvou betónu sa nachádzalo $10 \mathrm{~cm}$ zásypu a následne vnútorný základový odstup múrov barokového kostola. Mimo základový odstup sa nám v sonde 6 podarilo dostat' iba na prvých 3 metroch výkopu (miesto pod vežou), následne sme sondu kopali iba do hĺbky $20 \mathrm{~cm}$ od nultého bodu v priestore lode kostola. Výkop sa často krížil s existujúcimi inžinierskymi siet’ami. V priestore presbytéria sa nám podarilo sondu prehĺbit' až na $40 \mathrm{~cm}$. Po odstránení súčasnej mramorovej dlažby (niveleta 0 ) sme pod maltovým lôžkom $-4 \mathrm{~cm}$ od nultého bodu zachytili zvyšky po maltových lôžkach pôvodnej kamennej podlahy. Medzi 6 až 8,8 metrom sondy 6 sme zachytili maltové lôžko s ôsmimi zachovanými odtlačkami pôvodnej kamennej dlažby barokového kostola. Pravdepodobné rozmery pôvodnej dlažby boli $40 \times 40 / 50 \mathrm{~cm}$. V zásype v presbytériu sme našli aj zlomky tejto kamennej dlažby zeleno-sivej farby. Na stenách sa nám podarilo identifikovat' relikty pôvodnej barokovej sivej omietky. Zásyp nad základovým odstupom neobsahoval žiadne zlomky keramiky, iba menšie fragmenty l'udských kostí, ktoré súvisia so starším kostolným cintorínom.

\section{Sonda $7 / 2017$}

Sonda 7 s rozmermi $40 \times 2000 \times 40 \mathrm{~cm}$ sa podobne ako sonda 6 realizovala počas odvlhčovania (drenáže) obvodových stien kostola a siahala od rohu pri západnom hlavnom vstupe do kostola popri južnom líci obvodovej steny až po presbytérium. Najvrchnejšiu vrstvu sondy 7 tvorila mramorová dlažba vybudovaná v 50. rokoch 20. storočia. V juhozápadnom rohu kostola sa nám podarilo zachytit' aj západný múr staršieho gotického kostola (obr. 6). Hrúbka múru bola $100 \mathrm{~cm}$. Múr bol narušený výstavbou základov barokového kostola, ale korešponduje s orientáciou presbytéria gotického kostola zachyteného v exteriéri na východnej strane barokového kostola (obr. 5). V presbytériu barokového kostola sme zachytili aj základy oltárnej menzy, ktorá bola vybudovaná pravdepodobne v 19. storočí a pri výmene podlahy v 50. rokoch 20 . storočia bola odstránená.

\section{Sonda $8 / 2018$}

Sonda 8 s rozmermi $150 \times 150 \times 60 \mathrm{~cm}$ sa nachádzala v exteriéri, pri južnej stene lode. V sonde sme zachytili južný oporný pilier pôvodného gotického kostola, ktorý vystupuje z južnej steny barokového kostola. Oporný pilier bol široký $80 \mathrm{~cm}$ a nie je vylúčené, že jeho poloha môže naznačovat' juhozápadné nárožie gotického Kostola sv. Mikuláša.

\section{Sonda 9/2018}

Sondy 9A-E sa nachádzali v exteriéri, západne od kostola sv. Mikuláša a mali orientáciu sever-juh a východ-západ. Ciel'om sond 9A-E bolo identifikovat' priebeh ohradového múru kostolného cintorína na západnej strane kostolného areálu (obr. 2). Ako podklad k vytýčeniu sond sme použili geofyzikálny prieskum J. Tirpáka z rokov 2016-2017 (Tirpák 2017). Sondy 9A a 9B sme vytýčili oproti barokovému vstupu do kostola, na okraji betónového chodníka. Sondy mali orientáciu sever-juh, rozmery $100 \times 200 \mathrm{~cm}$ a v oboch sa nám podarilo po $15-20 \mathrm{~cm}$ od povrchu zachytit' západný priebeh ohradového múru cintorína. Základy ohradového múru boli široké okolo $80 \mathrm{~cm}$. Odkryli sme ho maximálne do nivelety $30 \mathrm{~cm}$ od zachytenia. Múr je zložený zo stredne vel'kých lomových kameňov spájaných maltou s menším podielom piesku. V sonde 9C 


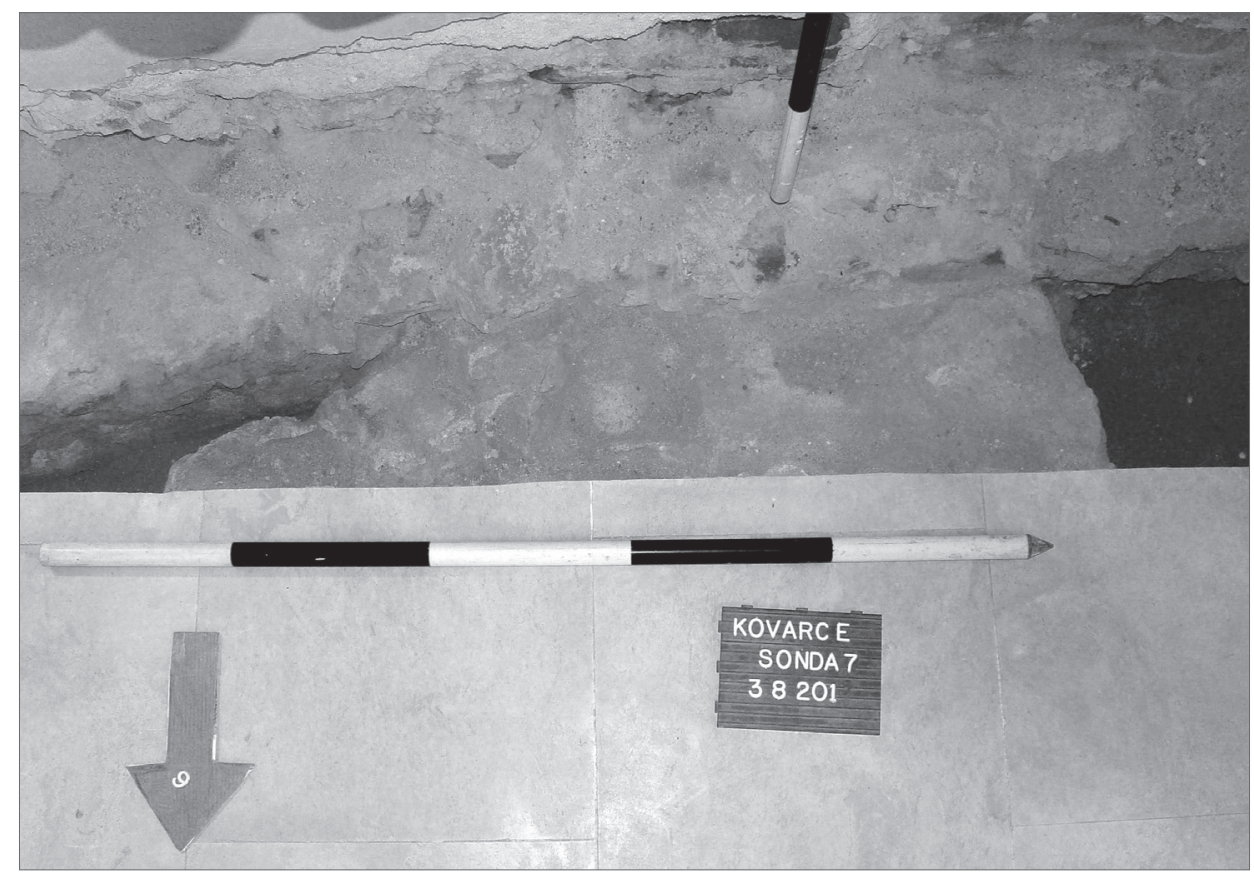

Obr. 6. Kovarce, Kostol sv. Mikuláša, sonda 7. Západný múr pôvodného gotického kostola zachytený pod mramorovou podlahou v interiéri kostola. Foto M. Bielich.

Abb. 6. Kovarce, St. Nikolauskirche, Sondierschnitt 7. Unter dem Marmorfußboden im Kircheninnern erfasste Westmauer der ursprünglichen gotischen Kirche. Foto M. Bielich.

pokračovanie ohradového múru nebolo zachytené kvôli silnému novodobému narušeniu terénu $\mathrm{v}$ tomto priestore. Išlo o výkopy pre inžinierske siete, ktoré sme zachytili v úseku popri ceste a na d’alších profiloch. Sondu 9D sme situovali do betónového chodníka a mala orientáciu východzápad. Po odstránení betónu sme v strede zachytili ohradový múr cintorína. Severozápadne od kostola do trávnatej plochy sme situovali poslednú sondu na západnej strane kostolného areálu, sondu 9E. V sonde sme zachytili pokračovanie priebehu ohrady až do úseku, kde bola porušená výkopom kanalizácie v roku 1978, ktorú dokumentoval A. Ruttkay (1978). Ohradový múr vznikol pravdepodobne v 16. storočí a stál do polovice 18. storočia.

\section{Sonda 10A-F/2018-2019}

Sondy 10A-E sa nachádzali východne od presbytéria kostola, v exteriéri. Terén v mieste sondy 10A-E tvorila trávnatá plocha. Ciel'om sondy 10A-E bolo identifikovat' a sledovat' priebeh východného ohradového múru kostolného cintorína. Priebeh múru presne kopíroval anomálie identifikované geofyzikálnym prieskumom z rokov 2016-2017 (J. Tirpák). Na základe geofyzikálneho prieskumu sme severovýchodne od rohu sakristie kostola vytýčili sondu 10A. Po znížení terénu o $30 \mathrm{~cm}$ sme zachytili relikty ohradového múru cintorína. Vo východnej časti sondy sme zdokumentovali kultúrnu vrstvu, ktorá obsahovala vel'ké množstvo keramiky zo 17.-18. storočia. Vytýčili sme sondy 10B a 10C. V oboch sme zachytili priebeh múru, ktorý mal šírku $80 \mathrm{~cm}$. Múr bol vystavaný zo stredne vel'kých lomových kameňov spájaných maltou s menším podielom piesku. Podarilo sa nám zachytit' iba jeho základy. V sonde 10C sme zdokumentovali zhluk kameňov okolo štvorcového otvoru. Mohlo by íst’ o kamennú pätku kríža v rámci cintorína. 
Medzi kameňmi sme objavili grajciar Leopolda I. z roku 1681. Sondu 10D sme situovali na okraj trávnatej plochy areálu kostola. Žial', v tejto sonde sme múr nezachytili, takže sme vytýčili sondu $10 \mathrm{E}$ s orientáciou sever-juh v bezprostrednej blízkosti sondy 10C. Následne sme preskúmali priebeh ohrady až po asfaltovú cestu. Počas výkopu piatich zist'ovacích sond západne od kostola sa nám podarilo v štyroch sondách doložit’ priebeh ohradového múru cintorína. Múr vznikol pravdepodobne v 16. storočí a stál do polovice 18. storočia. V roku 2019 sme pokračovali v identifikácii priebehu ohradového múru na východe. Počas výkopu južného rozšírenia zist'ovacej sondy $10 \mathrm{E}$ východne od kostola sa nám podarilo doložit’ priebeh ohradového múru cintorína a jeho postupné otáčanie južným smerom. Š́rka zachovanej časti základov múru je približne $80 \mathrm{~cm}$. Počas výkopu zist’ovacej sondy 10F severovýchodne od kostola sa nám podarilo doložit' priebeh ohradového múru cintorína a jeho postupné otáčanie severným smerom (obr. 7). Zároveň sme identifikovali betónové základy dažd’ovej kanalizácie, ktoré skúmal A. Ruttkay (1978).

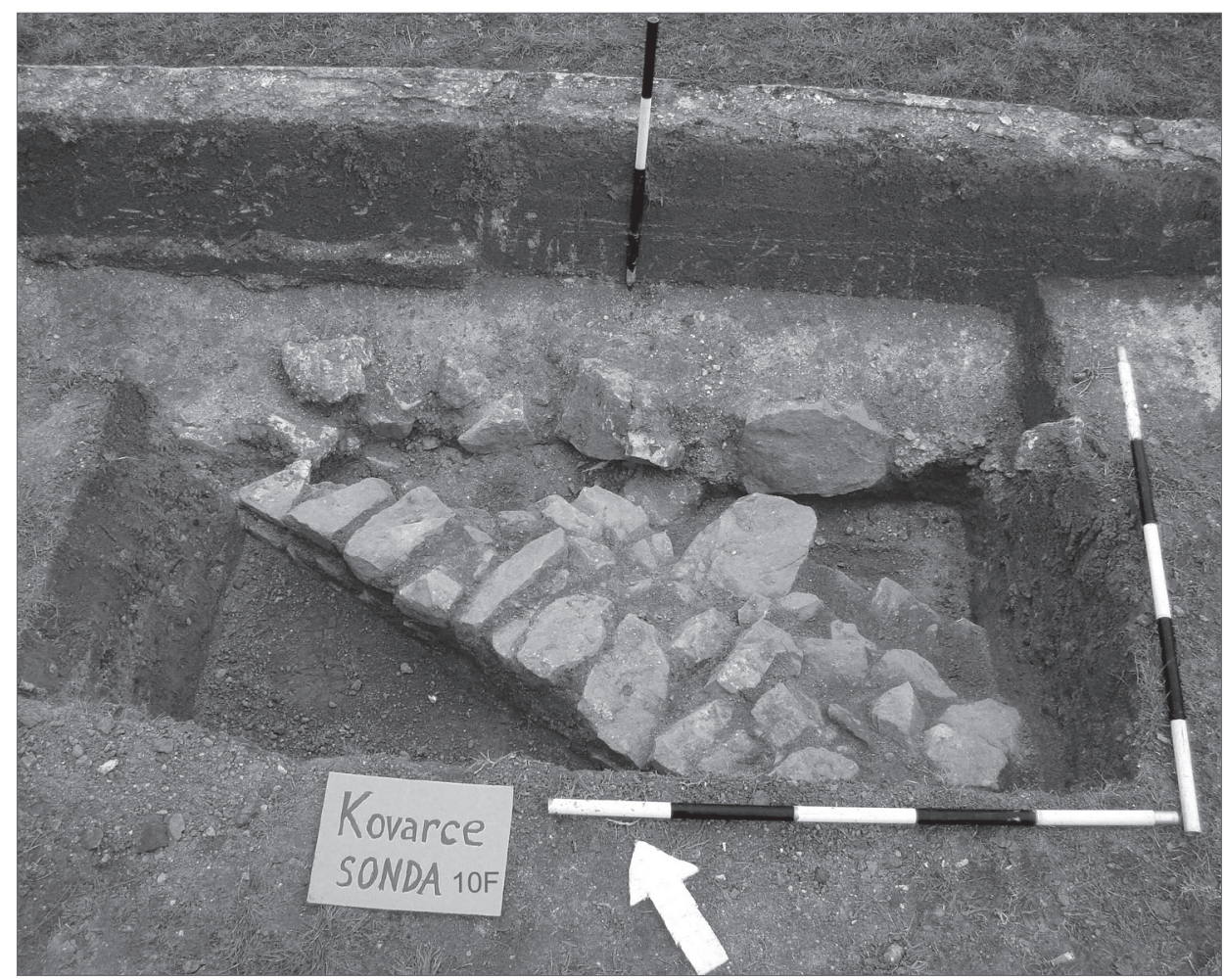

Obr. 7. Kovarce, Kostol sv. Mikuláša, sonda 10F. Ohradový múr cintorína narušený výkopom dažd’ovej kanalizácie. Foto M. Bielich.

Abb. 7. Kovarce, St. Nikolauskirche, Sondierschnitt 10F. Außenmauer des durch den Graben der Regenwasserkanalisation gestörten Friedhofs. Foto M. Bielich.

\section{Sonda 10G/2019}

Sonda 10 G s rozmermi $520 \times 60 \times 180 \mathrm{~cm}$ sa nachádzala juhovýchodne od Kostola sv. Mikuláša, pred budovou bývalých stavebnín. Ciel'om sondy bolo zachytit' priebeh ohradového múru. Zámer sa nepodarilo naplnit', nakol'ko ani po znížení skúmaného terénu v sonde o $90 \mathrm{~cm}$ sa stopy 
kamenného múru nezistili. V žltom sprašovom podloží boli objavené dva zahíbené sídliskové objekty. Objekt 1, zásobnicová jama hruškovitého tvaru s híbkou $180 \mathrm{~cm}$, sa nachádzal v západnom rohu sondy a z jeho zásypu pochádza vrcholnostredoveká a novoveká keramika. Na profile sa nejasne črtal starší objekt, ktorý bol narušený výkopom novovekej sídliskovej jamy. V strede sondy sme zachytili d’alší sídliskový objekt z novoveku.

\section{Sonda 10H/2019}

Sonda $10 \mathrm{H}$ s rozmermi $400 \times 200 \times 200 \mathrm{~cm}$ sa nachádzala na severovýchodnom rohu budovy firmy Okaver, južne od kostola. V sonde sa nám nepodarilo zachytit' priebeh ohradového múru cintorína. Výskum v sonde $10 \mathrm{H}$, najmä v jej severnej časti, bol limitovaný priebehom kábla vysokého napätia $(22000 \mathrm{~W}) \mathrm{s}$ ochranným pásmom $100 \mathrm{~cm}$. V sonde sa v žltom sprašovom podloží podarilo zachytit' dva sídliskové objekty v superpozícii. Objekt 1 je datovaný do vrcholného stredoveku a objekt 2 je novoveký (17.-18. storočie). V zásype objektov sa nachádzalo minimálne množstvo nálezov. Sonda $10 \mathrm{H}$ bola následne rozšírená o $200 \mathrm{~cm}$ západným smerom. Po znížení o $40 \mathrm{~cm}$ sme zachytili žlté sprašovité podložie, v ktorom sme identifikovali d'alšie tri sídliskové objekty (objekty $3-5$ ).

Vo východnej časti západného rozšírenia sondy $10 \mathrm{H}$ sme identifikovali menšiu kruhovú jamu (objekt 3) s híbkou $48 \mathrm{~cm}$. Obsahovala keramický materiál z vrcholného stredoveku (zlomky okrajov hrncovitých nádob s rytou výzdobou a zlomky okrajov zásobníc). V strede sondy $10 \mathrm{H}$ sme v smere severovýchod-juhozápad zachytili pás mazanice (objekt 4), pri ktorom pravdepodobne ide o deštrukciu staršej stavby. Na hrudkách mazanice sú dobre identifikovatel’né konštrukčné prvky sídliskovej stavby. V západnej časti sondy $10 \mathrm{H}$ sme zachytili kruhový objekt (objekt 5), pôvodne zásobnicovú jamu s híbkou $200 \mathrm{~cm}$ z obdobia novoveku, ktorá neskôr slúžila ako odpadová jama. Z jej zásypu pochádza vel'ké množstvo keramiky, skla a zvieracích kostí.

\section{Sonda 10I/2019}

Sonda 10I s rozmermi $350 \times 50 \times 70 \mathrm{~cm}$ sa nachádzala na severozápadnom rohu budovy firmy Okaver, juhozápadne od kostola. V strede sondy sme zachytili betónovú rúru dažd’ovej kanalizácie z nádvoria firmy Okaver (bývalé Kino). V severnej časti sondy sme zachytili čast' sídliskového objektu z vrcholného stredoveku. Objekt sme v priestore sondy plasticky vybrali. Jeho zásyp obsahoval najmä zlomky keramiky. Zásypová vrstva nad objektom obsahovala keramiku z druhej polovice 18. storočia. Najvrchnejšia vrstva súvisí so stavebnými úpravami okolo bývalej školy a pochádza z 20. storočia.

\section{Sonda 10J/2019}

Sondu $10 \mathrm{~J}$ s rozmermi $280 \times 180 \times 30 \mathrm{~cm}$ sme situovali do asfaltového prístupového chodníka juhozápadne od kostola. Ciel’om sondy bolo identifikovat' aspoň relikty ohradového múru južne od kostola, pretože tento priestor bol v 70. rokoch 20. storočia narušený výkopom troch inžinierskych sietí, ktoré väčšinu múru zničili. Sonda sa nachádzala medzi kanalizáciou a vodovodnou prípojkou. Podarilo sa nám zachytit’ relikty ohradového múru na juhozápadnom rohu sakrálneho areálu. Šírka zachovanej časti základov múru je približne $80 \mathrm{~cm}$. Odkryli sme ho maximálne do nivelety $20 \mathrm{~cm}$ od zachytenia. Múr bol vystavaný zo stredne vel'kých lomových kameňov spájaných maltou s menším podielom piesku.

\section{Sonda 10K/2019}

Sonda $10 \mathrm{~K}$ s rozmermi $900 \times 60 \times 30 \mathrm{~cm}$ sa realizovala ako reakcia na výkop prípojky dažd’ovej kanalizácie na kanalizáciu južne od kostola. Výkop bol hlboký iba $30 \mathrm{~cm}$. Prechádzal vrstvami 
zásypu cesty južne od kostola. Avšak podarilo sa nám zachytit’ priebeh všetkých inžinierskych sietí v tomto priestore $-500 \mathrm{~cm}$ od severnej steny firmy Okaver prebieha kábel vysokého napätia $(22000 \mathrm{~W}) ; 600 \mathrm{~cm}$ od budovy prebieha výkop vodovodu. Po $700 \mathrm{~cm}$ sme identifikovali korunu ohradového múru cintorína; 800-900 cm od budovy Okaver sa nachádza kanalizačná ryha.

\section{Nálezový fond}

\section{Keramika}

Keramika pochádza najmä zo sídliskových jám východne a južne od kostola, zistených v sondách 10A, 10G a 10H. Analyzovali sme spolu 2245 fragmentov z nádob a kachlíc. Získanú keramiku môžeme chronologicky rozdelit’ na keramiku vrcholnostredovekú, neskorostredovekú a novovekú. Najstaršiu skupinu nálezov reprezentujú zlomky vel'kých zásobníc (obr. 8:5, 7-10) z vrcholného stredoveku. Výzdoba je tvorená hrubými obežnými líniami (obr. 8:7, 8), alebo šikmými vrypmi (obr. 8:9, 10). Novovekú keramiku z Kovariec môžeme funkčne rozdelit' do dvoch skupín: keramiku stolovú (misy a taniere) a kuchynskú (hrnce, džbány, panvice s troma nôžkami). Z použitého materiálu dominuje obyčajná železitá hlina, ktorá po výpale získava typickú tehlovočervenú farbu, a iba minimálne sú zastúpené jemné hliny okrových a svetložltých farieb.
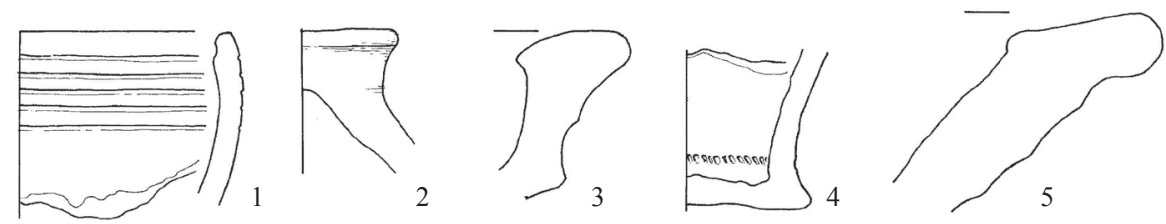

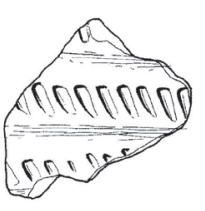

6

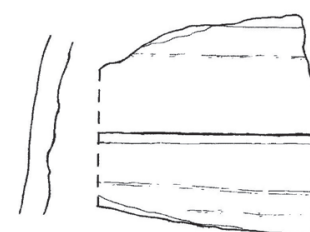

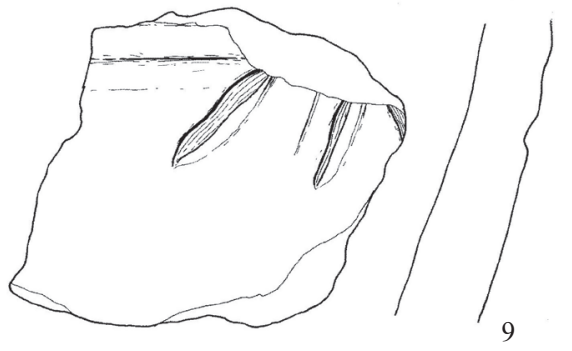

0

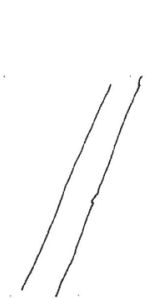

7
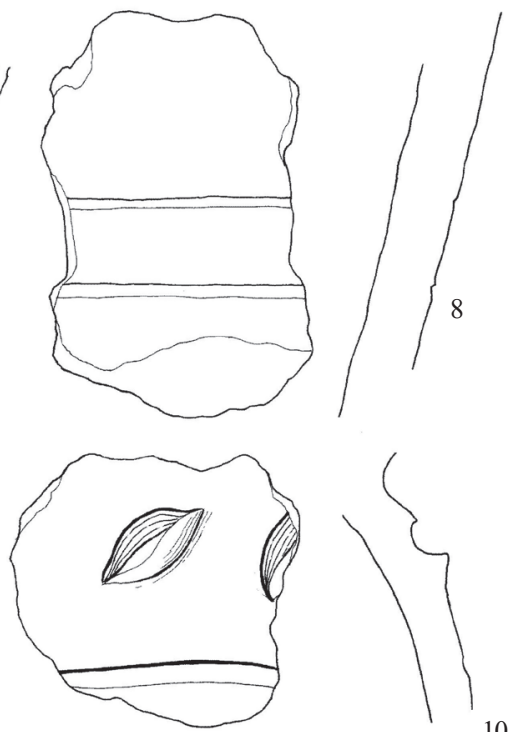

Obr. 8. Kovarce, Kostol sv. Mikuláša. Výber neskorostredovekej keramiky. Kresba Ž. Nagyová.

Abb. 8. Kovarce, St. Nikolauskirche, Auswahl spätmittelalterlicher Keramik. Zeichnung Ž. Nagyová. 
Pokial' to bolo možné sledovat' na niekol'kých fragmentoch okrajov a tiel, nádoby boli vytáčané na rýchlo rotujúcom hrnčiarskom kruhu. Prevažuje oxidačne pálená keramika s glazúrou zvnútra nádob a na horných okrajoch (obr. 9:3,9). Glazúra použitá na keramike bola transparentná zelená alebo bezfarebná. Výzdoba bola tvorená zväčša iba rytými obežnými líniami na pleciach a tele nádob (obr. 9:5, 8, 9). Na zlomku taniera sa objavuje žltá glazúra. Redukčne pálenú keramiku predstavuje keramika tvrdomestického typu, ktorej výrobu v kontexte hrnčiarskych lokalít v Prašiciach, Dolných a Horných Držkovciach, Čuklasovciach, Zlatníkoch a Dubodieli poznáme minimálne od prvej polovice 17. storočia (Kováč 1978, 125, 126). Zadymovaná keramika je zdobená väčšinou radielkom (obr. 8:6) a často je vysoko leštená. Najmladšiu keramiku reprezentujú nálezy zo sondy $10 \mathrm{G}$ (objekt 1) a sondy $10 \mathrm{H}$ (objekt 5). V oboch prípadoch ide vel'ké zásobnicové jamy, ktoré boli zasypané v priebehu 19. storočia. Keramika sa do ich zásypu dostala pravdepodobne ako odpad z ned’alekého kaštiel'a, resp. jeho hospodárskeho zázemia, čo naznačuje aj poloha objektov $\mathrm{v}$ sondách $10 \mathrm{G}-\mathrm{H}$ voči kaštiel'skemu areálu. Z rekonštruovaných tvarov ide o tzv. pyskaté džbánky z prostredia západoslovenskej l’udovej majoliky (Pišútová 1981, obr. 260, kat. 172, 260), rozmerné misy a rozličné formy nádob vysokých tvarov - zásobnicových hrncov s úzkym dnom i varných hrncov so širokým dnom, tzv. mašinárov (Hudáková-Hudák 2018, 20,
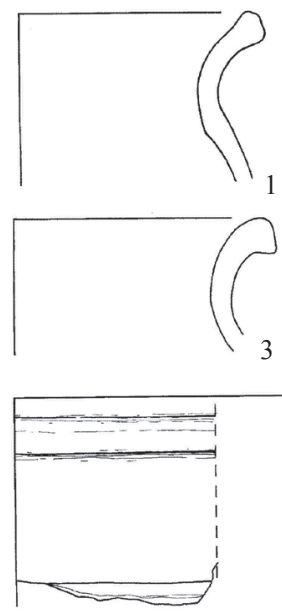

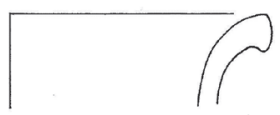

2

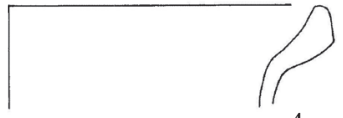

4
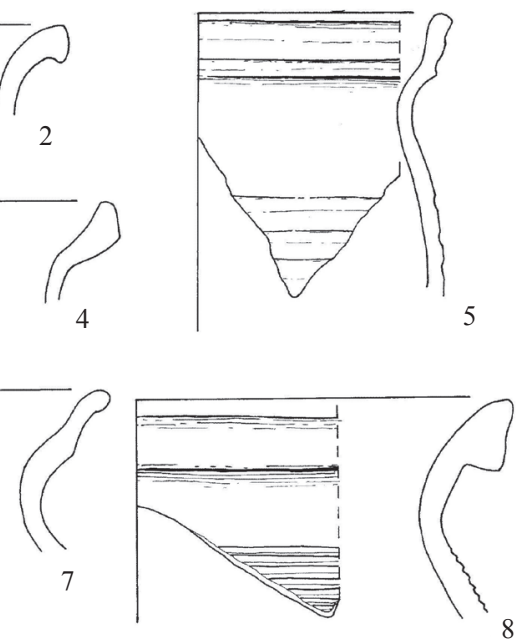
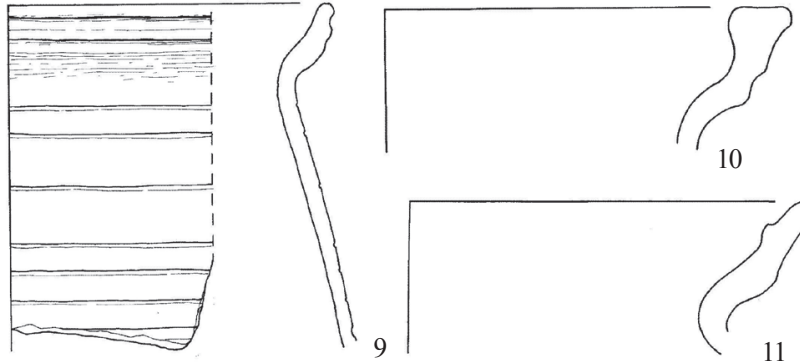

10
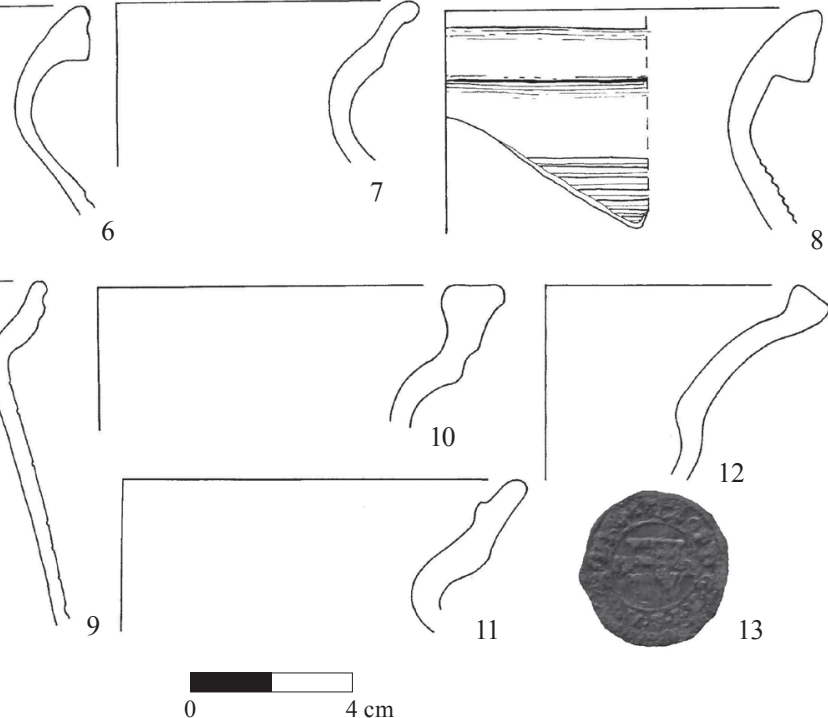
$4 \mathrm{~cm}$

Obr. 9. Kovarce, Kostol sv. Mikuláša. 1-12 - výber novovekej keramiky, 13 - grajciar Leopolda I. Kresba Ž. Nagyová; foto M. Bielich.

Abb. 9. Kovarce, St. Nikolauskirche. 1-12 Auswahl neuzeitlicher Keramik, 13 - Kreuzer Leopolds I. Zeichnung Ž. Nagyová; Foto M. Bielich. 
obr. 2; obr. 10). Posthabánska džbánkarská výroba na západnom Slovensku je - podobne ako jej habánske predlohy - charakteristická olovnato-ciničitou bielou glazúrou. Počas tureckých vojen sa znalost' výroby majoliky (fajansy) dostáva do Horného Uhorska prostredníctvom novokrstencov zrejme už v polovici 16. storočia. Habáni sa usídlovali prevažne na Záhorí, kde sú prítomní pravdepodobne okolo roku 1580, a následne aj na d’alších západoslovenských lokalitách. Vlastnej habánskej keramike dominovala žltá, modrá, zelená a fialová mal'ba na matnom bielom podklade (Kalesný 1981, 188, 189) a podstata tejto skladby sa postupne od záveru 17. storočia stala súčastou výtvarného prejavu aj l'udového džbankárstva s posledným vrcholom v priebehu 19. storočia.

Stavebnú keramiku môžeme rozdelit’ na kachlice, tehly a škridly. Kachlice sú iba komorové a pravdepodobne pochádzajú z bývalej fary, ktorá sa nachádzala západne od kostola alebo z kaštiel'a východne od kostola. Častým kachl’ovým výzdobným motívom je geometrický dekór v podobe mriežky (obr. 11:1-3), ktorý sa využíval bud' ako centrálna, alebo ako doplňujúca výzdoba. S podobným motívom sa stretávame na kachliciach z Oponického hradu (JančiováRepka-Sater-Styk 2019), hradu Gýmeš a hradu Hrušov. Všetky fragmenty sú glazované tmavozelenou glazúrou. Kachlice sú z červenej hliny, oxidačne vypálené. Niekol'ko fragmentov komorových kachlíc obsahuje malú miskovitú priehlbinu (obr. 11:4-6). Táto kachlica je glazovaná žlto-zelenou glazúrou. S rovnakým typom kachlice sa stretávame aj na Oponickom
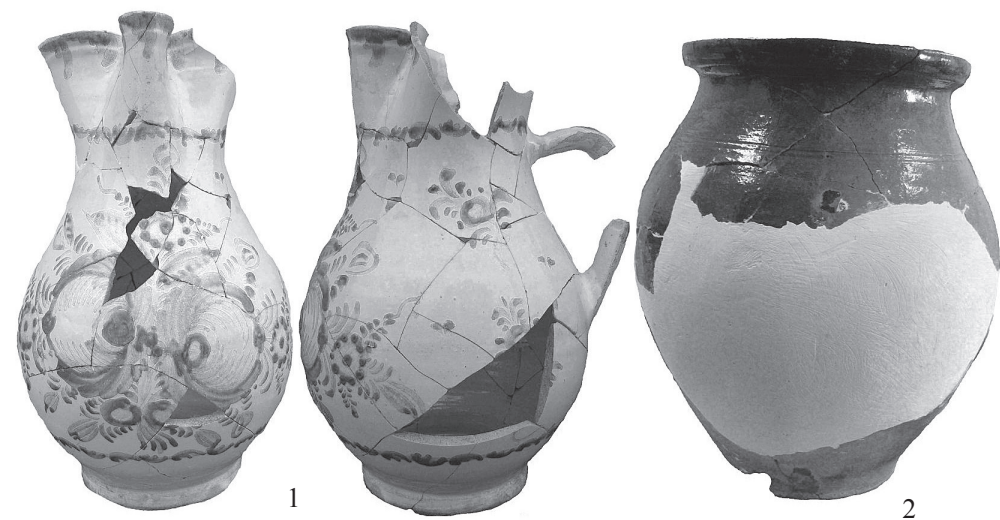

a
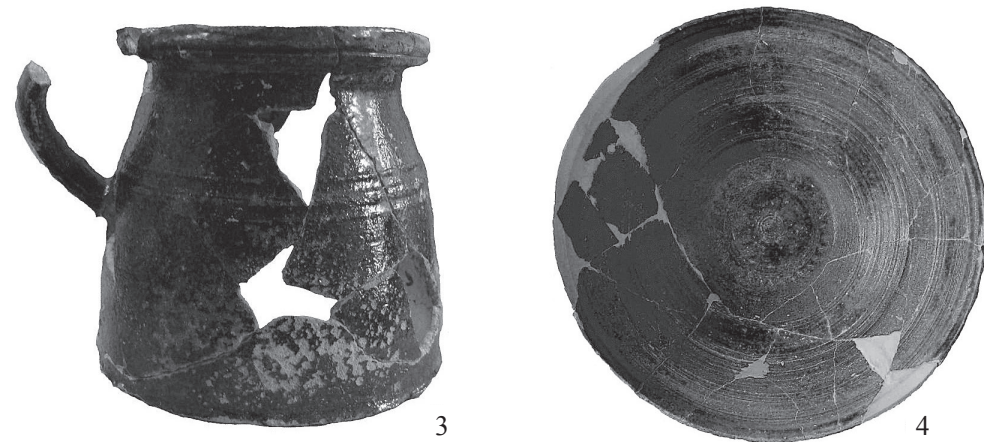

$\mathrm{b}$

Obr. 10. Kovarce, Kostol sv. Mikuláša. Výber novovekej keramiky. Foto M. Bielich.

Abb. 10. Kovarce, St. Nikolauskirche. Auswahl neuzeitlicher Keramik. Foto M. Bielich. 

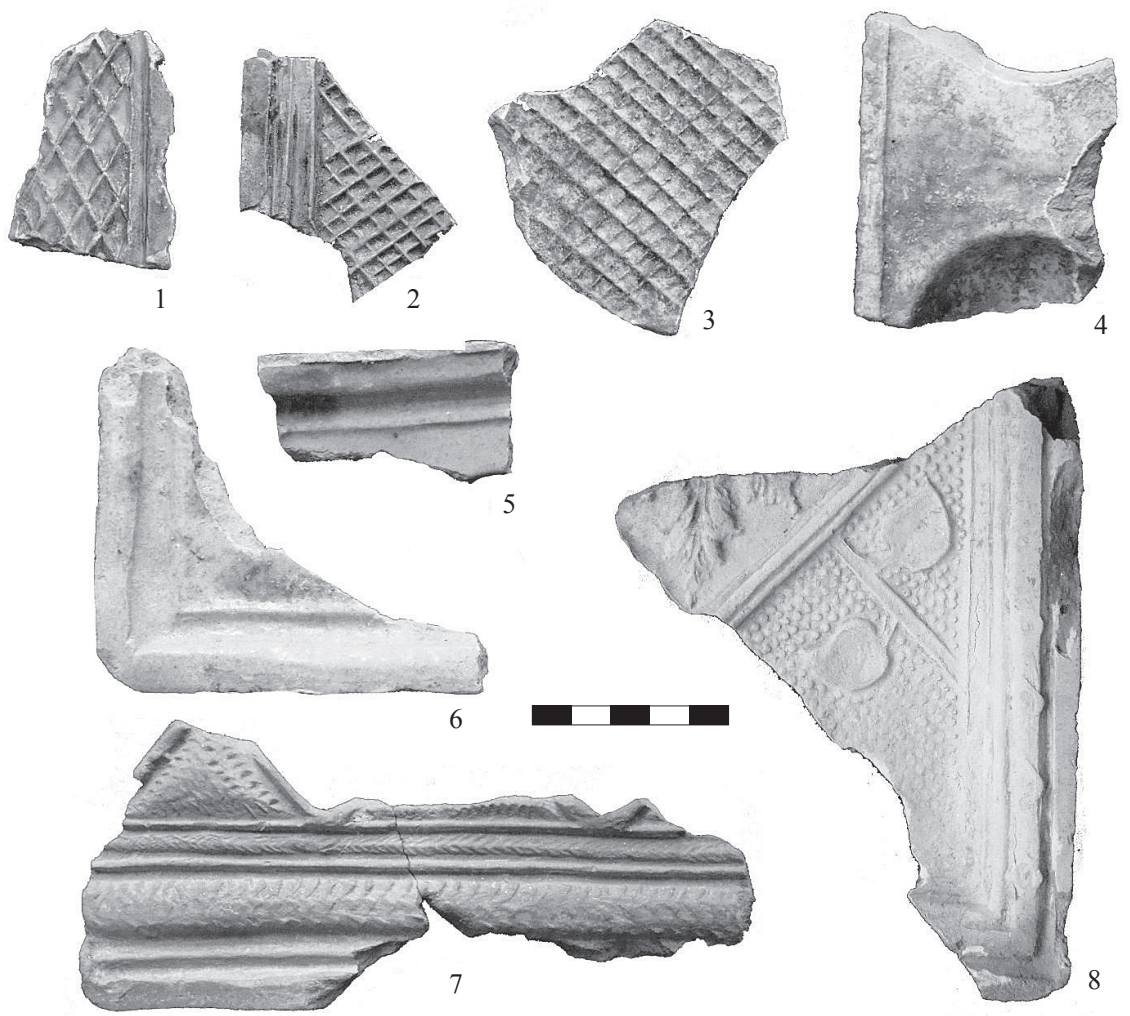

Obr. 11. Kovarce, Kostol sv. Mikuláša. Výber renesančných kachlíc. Foto M. Bielich.

Abb. 11. Kovarce, St. Nikolauskirche. Auswahl renaissancezeitlicher Kacheln. Foto M. Bielich.

(Bóna-Repka-Sater 2017, 58) a Topol’čianskom hrade. Na základe nálezových situácií je tento typ datovaný na koniec 16. až začiatok 17. storočia. Zaujímavým fragmentom kachlice je zlomok korunnej kachlice červenej farby, ktorý nie je glazovaný (obr. 11:7). Výzdoba kachlice je geometricko-rastlinná. Poslednú skupinu kachlíc reprezentuje kachlica kazetového typu, ktoré sú režnej okrovej farby (obr. 11:8). S týmto typom kachlice sa stretávame na hrade Orlík u Humpolce (Pavlík-Vitanovský 2004, 306, obr. 1232).

Z archeologického výskumu pochádza aj vel'ký počet tehiel. Z celkového počtu skúmaných tehiel z archeologických situácií pochádzajú dve tehly s kolkami a jedna s odtlačkom zvieracej (psej) labky s rozmermi maximálne $16 \times 14 \times 5 \mathrm{~cm}$ (obr. 12:3). Jedna z tehiel obsahuje iniciály donátorky výstavby kostola, grófky Judity Berényi (CBI). Druhá tehla obsahuje kolok CEI, ktorý patrí Erdődyovskej tehelni v Hlohovci, založenej v 17. storočí. Tento typ kolku sa objavuje až v druhej polovici 18. storočia a patrí majitel’ovi tehelne, grófovi Josefovi Erdődymu (Comes Iosephus Erdődy). Pre všetky je typické použitie silno železitej hliny s prídavkom ostriva - piesku. Všetky tehly pochádzajú zo sondy 1 a boli objavené priamo v barokovej podlahe, alebo v zásype miestnosti pod barokovou podlahou. Tehly pochádzajú z druhej polovice 18. storočia. V tomto období boli kolkované tehly vyrábané v tehelniach v okolitých dedinách Oponice a Ludanice (Čurný 2006, tab. 3:2). 


\section{Opis tehiel}

1. Tehla s vystupujúcimi písmenami kolku CBI (Commes Berényi Iudita), rozmery: $29,5 \times 14,5 \times 5 \mathrm{~cm}$, datovanie: druhá polovica 18 . storočia (obr. 12:1).

2. Tehla s vystupujúcimi písmenami kolku CEI (Commes Erdödy Iosephus), rozmery: $30 \times 15 \times 5 \mathrm{~cm}$, datovanie: druhá polovica 18. storočia (obr. 12:2).

Vel'ký súbor keramickej krytiny sa nám podarilo objavit' $\mathrm{v}$ severnej časti sondy 10A. Išlo pravdepodobne o odpadovú jamu z 20. storočia. Jama bola zahĺbená do podložia a obsahovala iba úlomky korýtkovej krytiny červenej farby, ktoré pravdepodobne súvisia s rekonštrukciou strechy sakristie v 20. rokoch 20. storočia. Najzachovalejší exemplár má dížku približne $30 \mathrm{~cm}$ a šírku $16 \mathrm{~cm}$. Korýtková krytina patrí medzi najstaršie typy keramických krytín striech. Rozšírená bola najmä v oblasti Stredomoria a Jadranu. Táto krytina bola na Slovensku známa nepochybne najneskôr už od 15 . storočia.
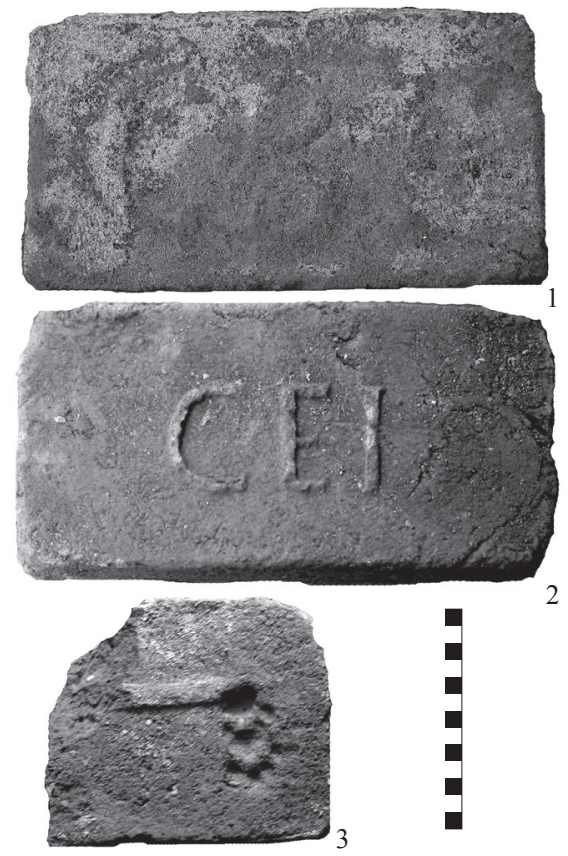

Obr. 12. Kovarce, Kostol sv. Mikuláša. Výber novovekých tehiel. Foto M. Bielich.

Abb. 12. Kovarce, St. Nikolauskirche. Auswahl neuzeitlicher Ziegeln. Foto M. Bielich.

\section{Drobné predmety}

Z archeologického výskumu pochádza vel’mi málo drobných predmetov. Najpočetnejšie sú zastúpené nálezy železných kovaných klincov (17 kusov). Ide o klince typu T (Polla 1962, 134, Slivka 1981, 24). Železné klince indikujú pôvodnú prítomnost' drevených rakiev, zbíjaných z dosiek. Zachovalost' drevených častí rakiev na kostolných cintorínoch sa viaže spravidla k mladším fázam ich existencie. Rakvy sa zachovávajú väčšinou iba v interiéri kostolov. A. Vallašek preskúmal v okolí dnešného Chrámu sv. Mikuláša v Bratislave hroby, ktoré boli bez výnimky uložené v drevených rakvách. Hroby patria ku kostolu postavenému po roku 1661 (Vallašek 2003, 113). V Kovarciach sme v exteriéri nenašli stopy po organických častiach rakiev. Jediná zachovaná rakva bola dokumentovaná v krypte pod severnou sakristiou a tá bola kovová. Rakva bola bohato zdobená rastlinnými rozvilinkami na rohoch a železným krížom na veku. Ďalšiu skupinu železných predmetov predstavujú podkovičky čižiem či inej obuvi objavené v zásypoch v okolí kostola.

Samostatnú skupinu nálezov predstavujú fragmenty textilu z rakvy A. Welsa. Tento typ nálezov zatial' nebol podrobený hlbšej analýze. Nájdené fragmenty textilu boli iba zakonzervované. Môžeme ich rozdelit' na dve skupiny: fragmenty textílíi z rakvy a textílie z odevu pochovaného. Vnútro rakvy bolo potiahnuté fialovou látkou, bližšie neurčenou. Odev A. Welsa bol čiernej farby. Skladal sa z nohavíc, saka a bielej košele. Na saku bol zachytený manžetový gombík.

Pri výskume bola objavená iba jedna novoveká minca, a to v sonde 10C. Ide o grajciar Leopolda I. z roku 1681 (obr. 9:13). ${ }^{2}$ Miestom nálezu bol zhluk kameňov okolo štvorcového otvoru vnútri kostolného cintorína. Mohlo by íst' o kamennú pätku kríža v rámci cintorína. $\mathrm{V}$ sonde 1/2016 sme medzi tehlami, ktorými bol uzatvorený vstup do miestnosti pod vežou, našli dva

2 Za určenie mince d’akujeme numizmatikovi J. Hunkovi z AÚ SAV v Nitre. 
dvadsat'halierniky z rokov 1921 a 1924. Ide o roky rekonštrukcie interiéru kostola.

Zaujímavým nálezom je manžetový gombík z odevu A. Welsa, na ktorom sa nachádza egyptský motív (obr. 13). ${ }^{3}$ Ide o zobrazenie uctievania tróniaceho egyptského božstva, ktoré sa vyskytuje vo všetkých faraónskych obdobiach. Postavy sú však vel’mi neegyptské. Tróniaca mužská postava má pokrývku hlavy panovníka, ale podla toho, že má napríklad zobrazené celé telo jednou farbou bez odlíšeného odevu, mohlo by íst' aj o boha - Usira. ${ }^{4}$ Trón je egyptský. Žezlo je zaujímavé - väčšinou býva ovel'a schematickejšie, ale $\mathrm{v}$ tomto prípade je zobrazená jasná zvieracia hlava. Proporcie a kompozícia sú nerovnomerné. Neegyptské sú farby a pozadie. Ide pravdepodobne o kópiu z druhej polovice 19. storočia.

\section{Záver}

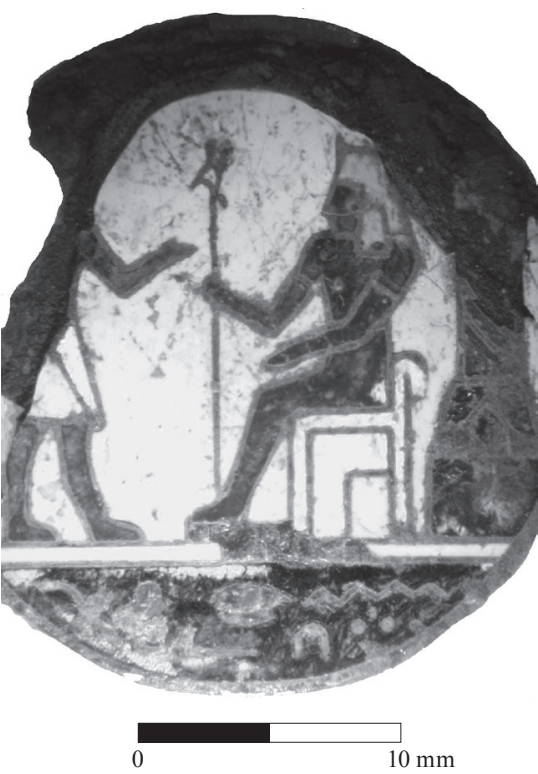

V rokoch 2016-2019 sa uskutočnil záchranný archeologický výskum Kostola sv. Mikuláša v Kovarciach, ktorý priniesol množstvo

Obr. 13. Kovarce, Kostol sv. Mikuláša. Manžetový gombík s egyptským motívom. Foto J. Mihályiová.

Abb. 13. Kovarce, St. Nikolauskirche. Manschettenknopf mit ägyptischem Motiv. Foto J. Miháliová. nových poznatkov o vývoji tohto stavebného objektu a jeho okolia v stredoveku a novoveku.

Prvotnou príćinou výskumu bol výkop teplovodnej prípojky medzi farou a kostolom. Neskôr sa uskutočnilo odvlhčenie základov kostola a následne výskum pokračoval sondážou v okolí. Výsledky archeologického výskumu boli základom projektu revitalizácie námestia.

Najstaršia doposial' známa sakrálna stavba v Kovarciach sa nachádza pod súčasným barokovým Kostolom sv. Mikuláša. Pri východnom múre barokovej svätyne kostola sme zdokumentovali v roku 2016 polygonálne presbytérium pôvodného gotického Kostola sv. Mikuláša. V západnej časti kostola pod vežou sme zachytili v roku 2017 základ západného obvodového múru najstaršieho gotického kostola. Tento múr je zachovaný vel'mi torzovito pri južnej stene vstupu do kostola. Pri južnej stene lode barokového kostola sa nám podarilo zachytit' v roku 2018 oporný pilier južnej steny gotického kostola. Na základe týchto výsledkov vieme odhadnút' vel'kost' pôvodného gotického Kostola sv. Mikuláša (obr. 2). Kostol bol dlhý približne 25 metrov a široký 10 metrov.

Okolo kostola bol vybudovaný ohradový múr, ktorý oddel’oval sakrálny priestor od profánneho územia obce. Najstaršie murované ohrady kostolov vznikajú na sklonku 14., resp. na začiatku 15. storočia (Slivka 2004, 16). Primárnym účelom vonkajšieho areálu kostola bolo síce poskytnutie posledného odpočinku farníkom, spíňal však aj iné poslania. Ohradenie tiež vyplývalo z nevyhnutnosti vymedzenia územia spadajúceho pod cirkevné právo (Unger 2006, 59). Základy múru boli skúmané v rokoch 2018-2019. Múr sme zachytili iba východne a západne od kostola. Šírka základov múru sa pohybovala okolo $80 \mathrm{~cm}$. Severná a južná čast' múru bola zničená výstavbou cesty spájajúcej Ludanice s Kovarcami. Z výskumu pri ohradovom múre pochádza zväčša renesančná keramika zo 16.-17. storočia. Múr bol pravdepodobne rozobratý počas výstavby barokového kostola.

\footnotetext{
3 Za určenie a spracovanie gombíka d'akujem V. Dubcovej.

4 Pozri https://sk.wikipedia.org/wiki/Usir.
} 
V exteriéri kostola sme preskúmali tri kostrové hroby (orientácia východ-západ) bez nálezov. Ide pravdepodobne o relikty hrobov kostolného cintorína pôvodného gotického kostola. Po výstavbe barokového kostola sa pochovávalo na cintoríne v severnej časti obce, ktorý sa objavuje aj na prvom vojenskom mapovaní. Antropologická analýza hrobov sa neuskutočnila, pretože to neumožňoval nedobrý stav zachovania kostrových pozostatkov. Preto boli tieto po zdokumentovaní znovu zasypané.

Gotický kostol bol pre svoje statické problémy a zrejme i kapacitné dôvody rozobratý a v druhej polovici 18. storočia znovu postavený. Výskum v interiéri kostola v roku 2017 identifikoval pôvodnú tehlovú podlahu barokového kostola z druhej polovice 18. storočia v miestnosti na severe pod vežou.

V lodi, kde je podlaha z 50. rokov 20. storočia, sa nám podarilo objavit' pri severnej stene maltové odtlačky pôvodnej kamennej podlahy. V kostole sa nachádzajú dve krypty. Mladšia krypta je pod severnou sakristiou (druhá polovica 19. storočia). Staršia krypta sa nachádza pod oltárom a vstupuje sa do nej schodmi pod vít’azným oblúkom.

Pri severnej stene barokového kostola sme preskúmali schodisko do krypty pod sakristiou, ktoré bolo vybudované najskôr v druhej polovici 19. storočia. V krypte pod severnou sakristiou sme objavili pozostatky A. Welsa, pradeda britskej herečky Audrey Hepburn. Je zaujímavé, že v krypte mala byt' podl'a písomných prameňov uložená aj jeho manželka Katarína, rodená Schutzová, jej pozostatky tam však neboli. Krypta bola dvakrát otvorená. Prvýkrát pred druhou svetovou vojnou, ked' bol zrušený pôvodný vonkajší vstup do krypty, a druhýkrát asi počas vojny, ked' sa do krypty dostali vykrádači z priestoru sakristie. V rakve A. Welsa bol objavený manžetový gombík s egyptským motívom.

Južne od kostola sme odkryli osem sídliskových objektov. Ide zväčša o sídliskové jamy nezistenej funkcie a dve jamy zásobného charakteru (napr. sonda 10G, objekt 1), ktoré slúžili neskôr ako odpadové jamy. Zaujímavým objektom je objekt 4 v sonde $10 \mathrm{H}$, kde bola zistená vel'ká koncentrácia mazanice. Na mazanici sa nachádzajú odtlačky prútoviny. Mohlo by íst'o deštrukciu steny nadzemnej stavby. Z výskumu týchto objektov pochádzajú však hlavne nálezy keramiky, zvieracích kostí a drobných predmetov z obdobia novoveku, ale aj neskorého stredoveku. Ide najmä o zlomky hrncovitých nádob, mís a iných kuchynských nádob a kachlice. Medzi nálezmi kachlíc sa objavujú aj fragmenty z 18. storočia. Tieto fragmenty pochádzajú z budov hospodárskeho zázemia ned’alekého kaštiel’a. Nálezy z Kovariec nevybočujú z rámca keramiky z mladšieho novoveku, ktoré sú z najbližšieho okolia známe a publikované z Horných Lefantoviec a Kostolian pod Tríbečom (Borzová-Čurný-Pažinová 2010, 20-21) a svojou celistvostou i pomerne dobrým stavom zachovania predstavujú vítaný materiál na štúdium novovekej keramickej produkcie na Ponitrí a západnom Slovensku.

Aj posledné archeologické výskumy v Kovarciach potvrdzujú, že táto obec zohrávala v období neskorého stredoveku a novoveku významnú úlohu v strednom Ponitrí. Po vybudovaní nového barokového kostola (druhá polovica 18. storočia) a príchode podnikatela A. Welsa do Kovariec v druhej polovici 19. storočia sa obec ako centrum cukrovarníctva a t’ažby dreva začala hospodársky vzmáhat'. Išlo však iba o dočasný rozmach, po smrti vlastníka Antona Welsa v roku 1876 nastal jej prirodzený hospodársky útlm.

Ďalšou fázou výskumu bola antropologická analýza kostrových pozostatkov A. Welsa, ktorá sa realizovala na Katedre antropológie PriF UK v Bratislave pod vedením S. Bodorikovej. Podla záznamu v matrike zomrel Anton Wels vo veku 46 rokov (1830-1876) na tamponádu srdca (hidropspericardi). Na jeho kostrových pozostatkoch sme identifikovali patologické zmeny (predčasná osifikácia tzv. permanentných chrupiek), ktoré indikujú, že A. Wels trpel nejakým endokrinným alebo metabolickým ochorením. Či toto ochorenie mohlo prispiet' ku vzniku tamponády srdca, nie je možné s určitost’ou tvrdit' (Bielich a kol. v tlači).

Príspevok vznikol v rámci projektu APPV-16-0449 „Stredoveká Nitra v hmotných prameňoch“. 


\section{Pramene a literatúra}

BIELICH, M. a kol., v tlači: Bielich, M.-Bodoriková, S.-Dörnhöferová, M.-Rajnic, T.-Piecková, E.-Dubcová, V., Výsledky výskumu Kostola sv. Mikuláša v Kovarciach v rokoch 2016-2019, ŠZ AÚ SAV.

BÓNA, M.-REPKA, D.-SATER, P., 2017: Oponický hrad. Dejiny, výskum a obnova pamiatky. Nitra.

BORZOVÁ, Z.-ČURNÝ, M.-PAŽINOVÁ, N., 2010: Nové poznatky o stredovekom a novovekom osídlení Horných Lefantoviec a Kostolian pod Tríbečom, ŠZ AÚ SAV 47, 5-24.

BŘEZINOVÁ, G., 1979: Kovarce, poloha: dom pána Pecháča. Nálezová správa č. 9055/79, ulož. v Archíve AÚ SAV v Nitre.

ČURNÝ, M., 2006: Poznatky o výrobe a značkovaní tehiel na území mesta Nitra a na jeho okolí v období novoveku, Archeologia technica 17, 52-65.

HUDÁKOVÁ, M.-HUDÁK, M., 2018: Keramické artefakty z výskumu zaniknutej sklárskej huty Richwald vo Vel'kej Lesnej, Spiš 9, 18-28.

JANČIOVÁ, B.-REPKA, D.-SATER, P.-STYK, M., 2019: Kachlice z Oponického hradu. Nitra.

KALESNÝ, F., 1981: Habáni na Slovensku. Bratislava.

KATKINOVÁ, J.-KATKIN, S., 2002: Prieskum na hradisku Vel'ký Tríbeč, AVANS 2001, 83-84.

KLČO, M.-ILLÁŠOVÁ, L., 1993: História Kovariec. Nitra.

KOVÁČ, J., 1978: Z dejín hrnčiarstva a kachliarstva na hornom Ponitrí, Horná Nitra 8, 111-151.

MITÁS̆, V.-ŽÁČIK, M., 2011: Archeologické nálezy z Kovariec, AVANS 2008, 195-196.

MAZÚR, E.-LUKNIŠ, J., 1986: Geomorfologické členenie. Atlas SSR. Bratislava.

PAVLÍK, Č.-VITANOVSKÝ, M., 2004: Encyklopedie kachlů v Čechách, na Moravě a ve Slezsku. Praha.

PIŠÚTOVÁ, I., 1981: Fajansa. Bratislava.

POLLA, B., 1962: Stredoveká zaniknutá osada na Spiši (Zalužany). Bratislava.

ROD, M., 1954: Kovarce, poloha: Humnište. Nálezová správa č. 193/54, ulož. v Archíve AÚ SAV v Nitre.

- 1954a: Kovarce, poloha: Dielec. Nálezová správa č. 194/54, ulož. v Archíve AÚ SAV v Nitre.

RUTTKAY, A., 1973: Kovarce, poloha: Mlyn. Nálezová správa č. 5916/72, ulož. v Archíve AÚ SAV v Nitre. - 1978: Kovarce, poloha: Kostol sv. Mikuláša. Nálezová správa č. 5916/78, ulož. v Archíve AÚ SAV v Nitre.

SLIVKA, M., 1981: Stredoveké hutníctvo a kováčstvo na východnom Slovensku. 3. čast', Historica Carpatica 12, 211-276.

- 2004: Hranica v mentálnom chápaní stredovekého človeka - Grenze in der Mentalwahrnehmung des mittelalterlichen Menschen, AH 29, 9-36.

TIRPÁK, J., 2017: Kovarce, poloha: Kostol sv. Mikuláša. Odborný posudok nedeštruktívneho archeologického výskumu geofyzikálnym meraním, ulož. v Archíve UKF v Nitre.

UNGER, J., 2006: Pohřební ritus 1. až 20. století v Evropě z antropologicko-archeologické perspektivy. Brno. VALLAŠEK, A., 2003: Neznáma rotunda pod Bratislavským hradom, Zborník FF UK 24, 111-122.

VELIAČIK, L.-ROMSAUER, P., 1994: Vývoj a vzt’ah osídlenia lužických a stredodunajských popolnicových polí na západnom Slovensku. Katalóg. Nitra.

VLASTIVEDNÝ SLOVNÍK OBCÍ 1977: Vlastivedný slovník obcí. 2. čast'. Bratislava.

WIEDERMANN, E., 1985: Archeologické pamiatky topol’čianskeho múzea. Nitra.

- 1987: Kovarce, poloha Vinohrad. Nálezová správa č. 11847/87, ulož. v Archíve AÚ SAV v Nitre.

\section{Zusammenfassung}

\section{Bericht über die in den Jahren 2016-2019 durchgeführte archäologische Grabung an der St. Nikolauskirche in Kovarce (Bezirk Topol’čany)}

In den Jahren 2016-2019 erfolgte an der St. Nikolauskirche in Kovarce eine archäologische Grabung, die trotz ihres geringen Umfangs eine Fülle neuer Erkenntnisse brachte hinsichtlich der Entwicklung dieses Bauobjektes und dessen Umgebung im Mittelalter und in der Neuzeit. Primärer Anlass für die Grabung war die Verlegung eines Warmwasseranschlusses zwischen dem 
Pfarrhaus und der Kirche. Später wurden die Fundamente der Kirche von der Feuchtigkeit befreit, im Anschluss daran wurde die Grabung mit Sondiergrabungen in der Umgebung fortgesetzt.

Während den Erdarbeiten wurden mehrere archäologische Situationen dokumentiert. Bei der Grabung im Kircheninnern wurde nördlich unter dem Turm der ursprüngliche Ziegelfußboden identifiziert (2. Hälfte 18. Jahrhundert). Im Kirchenschiff, in dem sich ein Fußboden aus den fünfziger Jahren des 20. Jahrhunderts befindet, konnten wir an der Nordwand Mörtelabdrücke des ursprünglichen Steinfußbodens entdecken. In der Kirche gibt es zwei Krypten. Die jüngere Krypta befindet sich unter der nördlichen Sakristei (2. Hälfte 19. Jahrhundert). Die ältere Krypta befindet sich unter dem Altar und wird über die Treppen unter dem Triumphbogen betreten.

Im Westteil der Kirche haben wir unter dem Turm die Westmauer der älteren gotischen Kirche erfasst. Diese Mauer ist an der Südwand nur sehr torsohaft erhalten geblieben. Im Außenraum der Kirche haben wir drei Skelettgräber untersucht (Ost-West-Orientierung), in denen sich keine Funde befanden. Bei ihnen handelt es sich um Reste des Kirchenfriedhofs, der aufgrund der Existenz der gotischen Kirche nur grob in die Zeit des 14.-18. Jahrhunderts datiert werden kann. Ab dem 18. Jahrhundert fanden die Beisetzungen auf dem Dorffriedhof außerhalb des Sakralbaus statt. Dieser Friedhof ist auch auf der ersten militärischen Kartierung eingezeichnet. An der Ostmauer der Kirche haben wir den polygonalen Chorraum der ursprünglichen gotischen St. Nikolauskirche dokumentiert. An der Südseite des Hauptschiffs der barocken Kirche konnten wir einen Stützpfeiler der Südwand der gotischen Kirche erfassen. Anhand dieser Ergebnisse können wir die Größe der ursprünglichen gotischen St. Nikolauskirche abschätzen. An der Nordwand der barocken Kirche haben wir die Treppe zur Krypta unter der Nordsakristei untersucht. Diese Treppe ist wahrscheinlich in der zweiten Hälfte des 19. Jahrhunderts angelegt worden. In der unter der Nordsakristei befindlichen Krypta haben wir die Gebeine von A. Wels, dem Urgroßvater der amerikanischen Schauspielerin Audrey Hepburn entdeckt. Die Krypta ist zweimal geöffnet worden. Zum ersten Mal vor dem zweiten Weltkrieg, als der ursprüngliche Außeneingang in die Krypta entfernt wurde, und das zweite Mal wohl während des Krieges, als sich Einbrecher aus dem Innenraum der Nordsakristei Zugang zur Krypta verschafften. Im Grab von A. Wels wurde ein Manschettenknopf mit einem ägyptischen Motiv entdeckt. Der älteste Sakralbereich in Kovarce war während der Renaissance von einer Außenmauer umgeben, die im Jahr 2018 im Rahmen einer archäologischen Grabung untersucht wurde. Die Mauer haben wir lediglich östlich und westlich von der Kirche erfasst. Der nördliche und südliche Mauerteil wurde durch den Bau einer Straße zerstört. Von der Grabung an der Außenmauer stammt renaissancezeitliche Keramik aus dem 16.-17. Jahrhundert und jungneuzeitliche Keramik aus dem 18.-19. Jahrhundert. Es handelt sich vornehmlich um Bruchstücke von Gefäßen und Kacheln. Unter den Kachelfunden tauchen auch Fragmente aus dem 18. Jahrhundert auf. Diese Fragmente stehen am ehesten noch mit dem nahegelegenen Schloss und dessen Hinterland in einem Zusammenhang. Aufgrund der letzten archäologischen Grabungen können wir festhalten, dass Kovarce im Spätmittelalter und in der Neuzeit im mittleren Neutragebiet eine bedeutende Rolle gespielt hat.

Der vorliegende Beitrag entstand im Rahmen des Forschungsprogramms APPV-16-0449 Das mittelalterliche Neutra in materiellen Quellen.

Mgr. Mário Bielich, PhD., Archeologický ústav SAV, Akademická 2, 94921 Nitra, Slovenská republika, mariobielich@seznam.cz 

